Climate Change Economics, Vol. 9, No. 1 (2018) 1840013 (39 pages)

(C) The Author(s)

DOI: $10.1142 / \mathrm{S} 2010007818400134$

\title{
THE WELFARE CONSEQUENCES OF TAXING CARBON
}

\author{
DALE W. JORGENSON \\ Department of Economics, Harvard University \\ Littauer Center 122, Cambridge, MA 02138, USA \\ RICHARD J. GOETTLE* \\ Northeastern University, Boston, MA 02115, USA \\ Dale Jorgenson Associates, 433 NH Route, 119 East \\ Fitzwilliam, NH 03447, USA \\ r.goettle@northeastern.edu \\ MUN S. HO \\ School of Engineering and Applied Sciences \\ Harvard University, 29 Oxford St, G2C Cambridge, MA 02138, USA \\ PETER J. WILCOXEN \\ The Brookings Institution, 1775 Massachusetts Ave, NW \\ Washington, DC 20036, USA \\ The Maxwell School, Syracuse University \\ 426 Eggars Hall, Syracuse, NY 13244, USA \\ Received 29 September 2017 \\ Revised 21 December 2017 \\ Accepted 3 January 2018 \\ Published 20 March 2018
}

For EMF 32, we applied a new version of our Intertemporal General Equilibrium Model (IGEM) based on the North American Industry Classification System (NAICS). We simulated the impacts arising from the Energy Modeling Forum's broad range of carbon taxes under three revenue recycling options - lump sum redistributions, capital tax reductions, and labor tax cuts. We examined their consequences for industry prices and quantities, for the overall economy, and for the welfare of households, individuals, and society, the latter in terms of efficiency and equity. We rank recycling mechanisms from most to least favorable in terms of the magnitudes of their impacts on net social welfare — efficiency net of equity — recognizing that other objectives may be more important to policy makers and the public. Finally, we and the EMF 32 effort focus only on the economic effects of carbon taxation and revenue recycling; the environmental benefits arising from emissions reductions are not within our scope of study.

\footnotetext{
*Corresponding author.
}

This is an Open Access article published by World Scientific Publishing Company. It is distributed under the terms of the Creative Commons Attribution 4.0 (CC-BY) License. Further distribution of this work is permitted, provided the original work is properly cited. 
We find $\mathrm{CO}_{2}$ emissions abatement to be invariant to the chosen recycling scheme. This means that policy makers need not compromise their environmental objectives when designing carbon tax swap options. We also find additional emissions reductions beyond the scope of coverage and points of taxation.

Reducing capital taxes promotes new saving, investment and capital formation and is the most favorable recycling mechanism. In 2010 dollars, the welfare loss per ton abated ranges from $\$ 0.19$ to $\$ 3.90$ depending on the path of carbon prices. Reducing labor taxes promotes consumption and work through real-wage incentives and is the next most favorable recycling scheme. Here, the welfare loss per ton abated ranges from $\$ 11.09$ to $\$ 16.49$ depending on the carbon tax trajectory. Lump sum redistribution of carbon tax revenues is the least favorable recycling option. It incentivizes neither capital nor labor. Consequently, the damages to the economy and welfare are the greatest among the three schemes. With lump sum recycling, the welfare loss per ton abated ranges from $\$ 37.15$ to $\$ 43.61$ as carbon taxation becomes more aggressive. While this ranking is common among the participating EMF 32 models, the spread in our results is the greatest in comparison which we attribute to the substitution possibilities inherent in IGEM's econometrics, the absence of barriers to factor mobility, and likely differences in the manner in which tax incentives are structured.

We find welfare gains are possible under capital and labor tax recycling when emissions accounting is viewed from a top-down rather than a bottom-up perspective and carbon pricing is at an economy-wide average. However, these gains occur at the expense of abatement.

We find capital tax recycling to be regressive while labor tax recycling is progressive as is redistribution through lump sums. Moreover, we find that the lump sum mechanism provides the best means for sheltering the poorest from the welfare consequences of carbon taxation. Thus, promoting capital formation is the best use of carbon tax revenues in terms of reducing the magnitudes of welfare losses while the lump sum and labor tax options are the best uses for reducing inequality.

Keywords: Carbon taxation; climate policy; computable general equilibrium modeling; $\mathrm{CO}_{2}$ emissions; greenhouse gas emissions; emissions abatement; leakage; revenue recycling; recycling "haircut"; macroeconomic impacts; industry impacts; distributional impacts; household welfare; individual welfare; social welfare; welfare efficiency; welfare equity; quintiles; progressive; regressive; bottom-up verses top-down emissions modeling.

\section{Introduction}

Two of the study questions in the Energy Modeling Forum's EMF 32 are (1) how do the economic and distributional outcomes from taxing carbon depend on government uses of the resulting revenues and (2) how do these outcomes vary with the initial tax rate and the rate at which it escalates. EMF 32 explores these with a diverse group of models under a common set of operating assumptions. The results add to a growing consensus in the literature. Carbon taxation alone is considered regressive to income and expenditure (e.g., Metcalf et al. (2008) and Mathur and Morris (2012)), although not without qualification (Fullerton and Heutel, 2010; Rausch et al., 2010). There is agreement that the revenues from taxing carbon can be deployed beneficially to reduce existing distortionary taxes and that the US tax code provides mechanisms to shelter those most harmed (e.g., Blonz et al. (2010), Parry and Williams (2010), Rausch et al. (2010), Mathur and Morris (2012) and Rausch and Reilly (2012)). Dinan (2012) offers a multi-dimensional evaluation of seven options for reducing the impacts on lowincome households. Marron and Toder (2013) discuss the potential role for carbon 
taxes in corporate tax reform, recognizing the double regressivity of such a plan. Williams et al. (2014) find carbon-capital tax swaps to be most efficient but most regressive, carbon taxes with lump-sum rebates to be least efficient but most progressive, and carbon-labor tax pairings to be an intermediate option.

For EMF 32, we apply a new version of our Intertemporal General Equilibrium Model (IGEM). We simulate the impacts on individual, household and societal welfare arising from the broad range of carbon taxes and revenue recycling options posited for the EMF 32 model comparison. We follow the path from the introduction of a carbon tax-and-swap pairing to their effects on industry prices and quantities, and then consider their macroeconomic consequences from both the expenditure and income perspectives. We examine the welfare implications of these pairings in terms of both efficiency and equity. At the household level, these are measured by equivalent variations in lifetime full expenditure (goods, services, and leisure) for demographic groups. At the individual level, these same equivalent variations are examined by quintile. We apply a social welfare function that aggregates over the households and permits the decomposition of welfare change into changes in efficiency and equity. Through it, we consider both egalitarian and utilitarian aversions to inequality.

While our emphasis is on the above, we explore the carbon tax "haircut" that is of concern to policy makers and modelers alike. The haircut refers to the general equilibrium effect of having the actual offsetting reduction in existing taxes be less than expected from a simple, partial equilibrium, calculation of carbon tax receipts. We offer a temporal view of the carbon tax revenues that need to be retained to achieve the EMF 32 fiscal objectives.

Finally, we examine issues arising from the heterogeneity in prices that underlie transactions in Social Accounting Matrices (SAMs) and the incidence of carbon taxation. For pricing, this is the difference between emissions pricing according to attribution and emissions pricing at an economy-wide average. For incidence, this is a matter of coverage and which buyers bear the burdens of pricing carbon. In the extreme, these relate to the difference between modeling emissions bottom-up and modeling them top-down. By measuring the magnitude of this difference, we demonstrate its significance in model outcomes and, equally, in model and policy design.

The new IGEM is based on the North American Industry Classification System (NAICS) and is estimated econometrically over a time series of IO tables covering the years 1960-2010. It is structured around 36 industries and commodities -1 each of agriculture, construction, and transportation, 6 of energy, 15 of mining and manufacturing and 12 of services. Oil and gas mining now are separated and along with coal, refined petroleum and electric and gas utilities comprise IGEM's energy sectors. The manufacturing and services groups offer a more contemporary view of the U.S. economy; information technology sectors - hardware and software, wholesale and retail trade, finance, business services, education, and health and welfare are among the revised model aggregates. 
Table 1. Carbon tax scenarios: $\$(2010)$ per metric tonne $\mathrm{CO}_{2}$ equivalent $\left(\mathrm{mtCO}_{2}-\mathrm{e}\right)$.

\begin{tabular}{lcccr}
\hline Scenario title & Tax in 2020 & Growth rate & \multicolumn{2}{c}{ Transition to steady state } \\
\cline { 4 - 5 } & & & & \multicolumn{2}{c}{ Year } & Tax \\
\hline EMF Specified Tax Paths & & & & \\
$\$ 25 @ 1 \%$ & $\$ 25.00$ & $1.00 \%$ & 2050 & $\$ 33.70$ \\
$\$ 25 @ 5 \%$ & $\$ 25.00$ & $5.00 \%$ & 2050 & $\$ 108.05$ \\
$\$ 50 @ 1 \%$ & $\$ 50.00$ & $1.00 \%$ & 2050 & $\$ 67.39$ \\
$\$ 50 @ 5 \%$ & $\$ 50.00$ & $5.00 \%$ & 2050 & $\$ 216.10$ \\
\hline
\end{tabular}

Table 1 presents the four core scenario groups that form the EMF 32 carbon tax trajectories. The carbon tax paths begin growing in 2020 and by 2050 achieve a constant, steady-state level for future years in terms of GDP purchasing power. The four represent combinations of two starting carbon prices - \$25 and \$50 in 2010 dollars - and two growth rates - 1\% and 5\%. The tax burden falls on the inputs of fossil fuels for combustion in the residential, commercial, industrial, transportation, electric utility and government sectors.

We simulate IGEM under conditions of debt and deficit neutrality for both government and the rest of the world. We also assume the absence of border controls on the trade flows of energy-intensive or other goods and services. We return carbon tax receipts to the private sector through tax swaps while preserving the annual purchases of goods and services by government in the base case path. We employ three recycling mechanisms - lump sum redistribution, capital tax rate reductions, and labor tax rate reductions. For one scenario — \$25@ @\%, we also recycle using both lump sum transfers and capital tax rate reductions; one case with "equiproportional" changes where the average labor and capital tax rates are scaled equally, and one case where the rates are adjusted so that social welfare is halfway between the pure lump sum and pure capital tax cases. Aside from small price changes, the combination of deficit neutralities and unchanged real government spending places the adjustment burden of carbon taxes on domestic saving and investment and the international terms of trade.

We organize the remainder of our paper as follows. Section 2 provides a brief overview of IGEM's structure and equations with emphasis on household, individual and social welfare. We discuss emissions abatement in each scenario in Sec. 3. Section 4 describes the interindustry and macroeconomic adjustments to carbon taxes. Section 5 discusses our approach to determining the "haircut" associated with carbon tax policy. We examine the welfare implications of carbon taxation, first for households and individuals in Sec. 6, and next for society in Sec. 7. Section 8 highlights the differences in model outcomes from bottom-up versus top-down emissions modeling. Section 9 summarizes the major findings and conclusions from IGEM's application to the scenarios of EMF 32. We must emphasize that our focus, and that of EMF 32, lies only on the direct consequences of carbon taxation for the US economy and social 
welfare; there is no consideration of environmental or climate benefits from $\mathrm{CO} 2$ abatement.

\section{The IGEM-N Model and Implementation of EMF32}

The Intertemporal General Equilibrium Model (IGEM) of the U.S. economy is described in detail in Jorgenson et al. (2013). This paper uses a substantially revised version of that model and we summarize the key features here that pertain to emission accounting and welfare analysis of the carbon policies in EMF32. We call this version IGEM-N to signify that the industry structure is based on the North American Industry Classification System (NAICS). The detailed equations of the model are given in a separate Appendix (Jorgenson et al., 2017). ${ }^{1}$

\subsection{Production}

IGEM-N recognizes 36 sectors, of which 6 are energy related, including two for gas mining and gas utilities. ${ }^{2}$ There is an Information Technology equipment industry that has very high total factor productivity (TFP) growth that is projected to continue, and 12 service sectors with low projected TFP growth. The production sub-model is represented by a tier structure as in most multi-sector models; however, unlike most systems based on constant-elasticity-of-substitution (CES) functions with two aggregated inputs, we use a flexible cost function with up to four inputs. At the top tier, output in industry $j$ is made from capital (KD), labor (LD), energy (E), and nonenergy intermediates $(\mathrm{M})$ :

$$
\mathrm{QI}_{j t}(\mathrm{KD}, \mathrm{LD}, E, M ; t) \text {. }
$$

The translog cost function we use allows a greater flexibility in substitution between energy and capital, labor and nonenergy intermediates, compared to a nested function, e.g., $\mathrm{QI}_{j t}(\mathrm{VE}[\mathrm{KE}(\mathrm{KD}, E), \mathrm{LD}], M)$.

Second, the cost function allows productivity change to be affected by input prices, that is, technical change (the outcomes of applied technology) has an endogenous component. This effect is also referred to as "biased technical change"; a well-known example is the rising hires of highly educated workers even as the relative price of such workers was rising. This allows the model to project a continuing energy-using or energy-saving bias in technical change (a change that uses more, or less, energy over time as energy prices rise, separate from the contemporaneous substitution effect).

\footnotetext{
1“IGEM, a Model of U.S. Growth and the Environment. Version 20. Appendix A. Equations of the Model" by Jorgenson et al. (2017), is available at http://www.igem.insightworks.com/docs/. Also available are updated Chapters of Jorgenson et al. (2013) that describes the economic history based on this NAICS dataset.

${ }^{2}$ The 2013 version is based on the SIC and only identifies one "oil and gas mining" sector. That model was estimated over 1960-2005 data whereas the current version estimates the production, import, export and investment functions over 1960-2010 input-output data in NAICS.
} 
There is also an exogenous technical change component that allows us to project TFP growth that differs by industry according to historical rates. This means that relative prices in the future are quite different from base year prices. The estimated parameters are reported in the model documentation update, ${ }^{2}$ and the implied substitution elasticities have been reported to the EMF32 team. We note that a base case projection with our estimated parameters will differ from the EMF32 specifications for GDP growth and consumption of the various fossil fuels. We calibrate the model to these external requirements in a manner described in Jorgenson et al. (2013, Chapter 6).

\subsection{Relation between industry quantities and national totals}

The accounting of emissions is an accounting of energy inputs into industry and households, and this is often not a transparent exercise in a multi-sector model. We give a short explicit description here to highlight the pitfalls and confusion that might arise in reconciling the observed prices that differ by industry with the typical model assumption of a homogenous good. The main example is the coal mining industry where prices ( $\$$ per ton) paid by electric utilities differ substantially from prices paid by other industries; that is, a $\$ 100$ million worth of coal input in the input-output accounts buys very different number of tons for different industries.

In Eq. (1), for example, $\mathrm{QI}_{\mathrm{coal}, t}$ is the quantity index of output of the coal sector, and $\mathrm{PI}_{\text {coal }, t}$ is the price, i.e., the price of average coal. To simplify the discussion, we ignore imports and the distinction between industries and commodities in this section. The supply equal demand condition in value terms is written as:

$$
\mathrm{PI}_{\mathrm{it}} \mathrm{QI}_{i t}=\sum_{j} \mathrm{~PB}_{i j t} \mathrm{AA}_{i j t}+\mathrm{PB}_{i, C t} C_{i t}+\mathrm{PB}_{i, G t} G_{i t}+\mathrm{PB}_{i, X t} X_{i t}
$$

where $\mathrm{AA}_{i j t}$ is the quantity of $i$ bought as intermediate inputs by industry $j$, and $C, G, X$ are household, government and export demand, respectively. $\mathrm{PB}_{i j t}$ denotes the buyer's price paid by $j$. Using data on actual prices (or actual quantities), we could write the quantity balance equation as:

$$
\mathrm{QI}_{i t}=\sum_{j} \xi_{i j t} \mathrm{AA}_{i j t}+\xi_{i C t} C_{i t}+\cdots,
$$

where the aggregation coefficients are given by the actual price data in some base year 0:

$$
\xi_{i j 0}=\mathrm{PB}_{i j 0} / \mathrm{PI}_{i 0} .
$$

If a model has an equation like (3), then the input quantity variable, $\mathrm{AA}_{\text {coal, } j t}$, would reflect the actual tons of coal used by $j$. Energy and emission accounts built off $\mathrm{AA}_{\text {coal, } j t}$ would be consistent with the EIA industry accounts. If a model ignores these observed differences in prices (assuming $\mathrm{PB}_{i j t}=\mathrm{PI}_{i t}$ ), and write the quantity 
balance as:

$$
\mathrm{QI}_{j t}^{\text {mean }}=\sum_{i} \mathrm{AA}_{i j t}^{\text {mean }}+C_{i t}^{\text {mean }}+\cdots,
$$

then the $\mathrm{AA}_{\text {coal, } j t}^{\text {mean }}$ variable could differ significantly from actual tons.

We refer to an accounting and modeling system using $\mathrm{QI}_{j t}^{\text {mean }}$ and Eq. (5) as top-down accounting, and that using $\mathrm{QI}_{j t}$ and $\mathrm{AA}_{i j t}$ in Eq. (3) as bottom-up accounting. A carbon tax implemented as a unit tax on output in the top-down system $\left(\mathrm{PI}_{\text {coal }, t}+t x_{\text {coal }, t}^{\mathrm{CO}}\right)$ is different from a unit tax on the buyer's price in the bottom-up system $\left(\mathrm{PB}_{\mathrm{coal}, j t}+t x_{\mathrm{coal}, t}^{\mathrm{CO} 2}\right)$. In the latter case, the percentage change in input price, $\left(\mathrm{PB}_{\text {coal }, j t}+t x_{\text {coal }, t}^{\mathrm{CO} 2}\right) / \mathrm{PB}_{\text {coal }, j t}$, differs by industry of use whereas every buyer sees the same percent change in the top-down model.

In the results section, we report the impacts of carbon taxes in both top-down and bottom-up accounting systems to highlight this distinction in modeling methods. We construct implicit buyer-specific prices using the emissions by fuel type by each major consuming sector. ${ }^{3}$

\subsection{Consumption and household welfare}

The household sub-model drives commodity demand in IGEM-N, determines labor supply and private savings. In this version, we have an aggregate Euler equation that determines aggregate full consumption and savings in each period. In the second stage, we have an aggregate function that determines commodity and leisure demand; a function that is a consistent aggregate over different household demands. This approach allows us to recognize the different consumption choices by different types of households, and to allow income elasticities to be different from 1 . The consistent (or, exact) aggregation condition means that the demand for commodity $i$ derived from the aggregate function is exactly equal to the sum over the demands for $i$ by different households:

$$
C_{i t}^{X}=\sum_{K} C_{i K t}^{X}
$$

The $K$ index runs over the demographic types (number of children: 0,1,2,3+; number of adults: 1,2,3+; region: Northeast, Midwest, South, West; urban/rural; male/ female and white/nonwhite head). There are 384 possible combinations of these characteristics, but only 244 are observed in the Consumer Expenditure Survey (CEX).

\footnotetext{
${ }^{3}$ Since our focus is on $\mathrm{CO} 2$ emissions from fossil fuel combustion, we use the estimates of emissions by fuel type for each major consuming sector in EIA's Monthly Energy Review and Annual Energy Outlook (AEO) 2016 to infer the implicit quantity of fuels. This procedure allows us to combine the differences in dollars per ton of raw coal, with the differences in coal quality and combustion ratios. This procedure is also useful for the differences in the types of liquid fuels and gas. Noncombustion $\mathrm{CO} 2$ and nonCO2 emissions are from EPA's Inventory of U.S. Greenhouse Gas Emissions and Sinks.
} 
The CEX sample consists of dozens of households in each group per year and for each group we have the actual distribution of household expenditures. The composition of household types is as follows: number of children - none $66 \%$, one $14 \%$, two $13 \%, 3+$ $7 \%$; number of adults - one $35 \%$, two $51 \%, 3+14 \%$; regions - Northeast $18.9 \%$, Midwest $23.0 \%$, South $36.5 \%$, West $21.6 \%$; location — urban $92.1 \%$; rural $7.9 \%$; race and gender of head - nonwhite females $7.4 \%$, white females $22.5 \%$, nonwhite males $10.3 \%$, white males $59.8 \%$.

This consistency is delivered by a somewhat complicated utility function at the top tier, $V(\mathrm{ND}, K, \mathrm{SV}, R)$; where the consumption bundles are nondurables (ND), capital services (K), services (SV), and leisure (R). We begin with the indirect utility function for household $k, V_{k}\left(p^{C}, m_{k} ; A_{k}\right)$ :

$$
\begin{aligned}
\ln V_{k} & =\alpha_{0}+\alpha^{H} \ln \frac{p}{m_{k}}+\frac{1}{2} \ln \frac{p^{\prime}}{m_{k}} B^{H} \ln \frac{p}{m_{k}}+\ln \frac{p^{\prime}}{m_{k}} B_{A} A_{k}, \\
p_{t}^{C \prime} & =\left(\mathrm{PC}_{\mathrm{ND}}, \mathrm{PC}_{K}, \mathrm{PC}_{\mathrm{SV}}, \mathrm{PC}_{R}\right),
\end{aligned}
$$

where $m_{k}$ is the total full expenditures of $k$ and $A_{k}$ is a $(0,1)$ indicator vector for demographic characteristics. "Full" refers to the sum of goods and leisure. The aggregate demand equation derived by adding over all households, in share form, is

$$
\begin{aligned}
& w_{t}=\frac{1}{D\left(p_{t}^{C}\right)}\left[\alpha^{H}+, B^{H} \ln p_{t}^{C}-B_{M}\left(\xi_{t}^{d d}+\ln M_{t}\right)+B_{A} \xi_{t}^{L}\right], \\
& w_{t}^{\prime}=\left(\frac{P C_{\mathrm{ND}} C_{\mathrm{ND}}^{X}}{M}, \frac{\mathrm{PC}_{K} C_{K}^{X}}{M}, \frac{\mathrm{PC}_{\mathrm{SV}} C_{\mathrm{SV}}^{X}}{M}, \frac{\mathrm{PC}_{R} C_{R}^{X}}{M}\right),
\end{aligned}
$$

where $M_{t}=\sum_{k} m_{k t}$ is the aggregate value of full expenditures (full income minus savings), and the $C_{i}^{X}$,s are the consumption quantities. $B_{M}$ gives the income elasticity and $B_{A}$ gives the different intercept values for different household types (e.g., households with children have a bigger share for nondurables). $\xi_{t}^{L}$ is a distribution term that represents the projected demographic changes in household structure that are paired with the $B_{A}$ coefficients. $\xi_{t}^{d d}$ is an exogenous term that depends on $\sum_{k} m_{k t} \ln m_{k t}$ and projects the changing share of total $M$ spent by households of type $K$. These distribution terms involve the projection of the number of households of each type derived from a population model.

The price elasticity matrix, $B^{H}$, is $4 \times 4$ matrix that allows a flexible substitution among the three commodity bundles and leisure; it is not restricted to a 2-input tier structure or a simple Linear Expenditure System. Below this top tier utility function, there is a nest of similar functions that allocates the three bundles to 36 commodities that are identified in IGEM-N. The parameters for the top tier are estimated over Consumer Expenditure Survey data (the CEX covers 4-8000 households per quarter), 1980-2006, the lower tiers use the Personal Consumption Expenditures in the National Accounts, 1960-2010. The estimates are given in Jorgenson et al. (2013, Chapter 3).

\footnotetext{
${ }^{4}$ The household model equations are given in detail in Jorgenson et al. (2017), Appendix A, Eq. (A1.12)-(A1.24).
} 
To compute household welfare, we begin with the model solution path for aggregate expenditure and prices: $M_{t}$ and $p_{t}^{C}$. We allocate the simulated aggregate expenditure to the different households using the projected number of households of each type $\left(n f_{K}\right)$ and computing the mean expenditure in type $K\left(M_{t}=\sum_{K} n f_{K t} \bar{m}_{K t}\right) .{ }^{5}$ The expenditures by type $K$ households are derived by holding them proportional to observed base year values:

$$
\bar{m}_{K t}=\mu_{K t}^{0} M_{t},
$$

where $\mu_{K t}^{0}$ depends on $n f_{K t}$ and the base year spending $\left(\bar{m}_{K}^{2006}\right)$. With this mean expenditure and prices, we compute the utility for type $K$ households for each period $\left(V_{K t}\right)$ using Eq. (7).

Household welfare is a discounted sum of this within-period $V_{k t}$. We regard households to be infinite-lived dynasties, and the utility of dynasty $d$ is

$$
V_{d}=\sum_{t=0}^{\infty} \delta^{t} \ln V_{d t}
$$

Jorgenson et al. (2017) shows how an intertemporal expenditure function, $\Omega_{d}\left(\left\{p_{t}\right\},\left\{\gamma_{t}\right\}, V_{d}\right)$, may be derived from the entire path of prices and interest rates, giving a dollar measure of dynastic utility. ${ }^{6}$ We call $\Omega_{d}$ "full wealth", and it equals the present value of the infinite stream of goods consumption and leisure. We emphasize that the demographic coefficients $\left(B_{A}\right)$ result in different values of $\Omega_{d}$ for the same levels of utility for different types of dynasties. This $\Omega_{d}$ function is used to compute the equivalent variation of a policy change that changes utility from $V_{d}^{0}$ in the base case to $V_{d}^{1}$ in the policy case.

$$
\Delta W_{d}=\operatorname{EV}_{d}=\Omega_{d}\left(\left\{p_{t}^{0}\right\},\left\{\gamma_{t}^{0}\right\}, V_{d}^{1}\right)-\Omega_{d}\left(\left\{p_{t}^{0}\right\},\left\{\gamma_{t}^{0}\right\}, V_{d}^{0}\right) .
$$

\subsection{Aggregate social welfare}

To discuss the policy impact on social welfare, in addition to calculating the impact on household welfare, we specify a social welfare function that takes into account both the mean and the distribution of household welfare.

$$
W=\bar{V}-\eta\left[\sum_{d=1}^{D} a_{d}\left|V_{d}-\bar{V}\right|^{-\mu}\right]^{-1 / \mu} .
$$

$\bar{V}=\sum_{d=1}^{D} a_{d} V_{d}$ is a weighted sum of dynastic welfare, where the weights are related to the number of "household equivalent members". Parameter $\mu$ is a measure of social aversion to inequality, where $\mu=-1$ gives the greatest weight to equity ( $W^{\text {Egalitarian }}$ ), and $\mu=-\infty$ gives an utilitarian function, where $W^{\text {Utilitarian }}=\bar{V}$.

\footnotetext{
${ }^{5}$ We also compute half and twice mean expenditure in each type $K$

6Jorgenson et al. (2017, Chapter 3), Eq. (3.67).
} 
Maximum social welfare $\left(W_{\max }\right)$ is attained by reallocating incomes to equalize welfare across dynasties (details in Jorgenson et al., 2017, Sec. 3.8).

$$
W_{\max }=\bar{V}=f\left(\frac{\Omega}{N^{\mathrm{eq}}}\right) .
$$

This maximum, or efficient, social welfare is a function of national full wealth $(\Omega)$ divided by the number of "household equivalent members", $N^{\text {eq }}$.

We derive a monetary measure of social welfare using a social expenditure function $\Omega\left(\left\{p_{t}\right\},\left\{\gamma_{t}\right\}, W\right)$ that depends on the entire time path of prices and interest rates. ${ }^{7}$ The national equivalent variation of a policy change $(\Delta W)$ is given by calculating the social full wealth, $\Omega$, for the base case social welfare $\left(W^{0}\right)$, and for policy case welfare $\left(W^{1}\right)$ at base case prices.

$$
\Delta W=\Omega\left(\left\{p_{t}^{0}\right\},\left\{\gamma_{t}^{0}\right\}, W^{1}\right)-\Omega\left(\left\{p_{t}^{0}\right\},\left\{\gamma_{t}^{0}\right\}, W^{0}\right) .
$$

We decompose this equivalent variation to a change in efficiency and a change in equity. The change in efficiency is the change in $\Omega$ measured at the perfectly egalitarian distribution of wealth

$$
\Delta E=\Omega\left(\left\{p_{t}^{0}\right\},\left\{\gamma_{t}^{0}\right\}, W_{\max }^{1}\right)-\Omega\left(\left\{p_{t}^{0}\right\},\left\{\gamma_{t}^{0}\right\}, W_{\max }^{0}\right) .
$$

The change in the money measure of equity $(\Delta \mathrm{EQ})$ is then given by the residual from (14) and (15)

$$
\Delta W=\Delta E+\Delta \mathrm{EQ} .
$$

When we report the policy impacts, we give the equivalent variation as a percent of full wealth, $\% \mathrm{EV}=\frac{\Delta W}{\Omega\left(\left\{p_{t}^{0}\right\},\left\{\gamma_{t}^{0}\right\}, W\right)}$.

We also define two measures of inequality in terms of the social expenditure function. An absolute index of equality may be defined as the difference between actual welfare and efficient welfare

$$
\left.\operatorname{AEQ}\left(\left\{p_{t}^{0}\right\},\left\{\gamma_{t}^{0}\right\}, W, W_{\max }\right)=\left[\Omega\left(\left\{p_{t}^{0}\right\},\left\{\gamma_{t}^{0}\right\}, W\right)\right]-\Omega\left(\left\{p_{t}^{0}\right\},\left\{\gamma_{t}^{0}\right\}, W_{\max }\right)\right]<0 .
$$

A relative measure of equality is:

$$
\operatorname{REQ}\left(\left\{p_{t}^{0}\right\},\left\{\gamma_{t}^{0}\right\}, W, W_{\max }\right)=\frac{\Omega\left(\left\{p_{t}^{0}\right\},\left\{\gamma_{t}^{0}\right\}, W\right)}{\Omega\left(\left\{p_{t}^{0}\right\},\left\{\gamma_{t}^{0}\right\}, W_{\max }\right)}<1 .
$$

The degree of progressivity of a policy change is given by two corresponding progressivity measures evaluating the inequality indices at base case and policy case welfare levels, both at base case prices

$$
\begin{aligned}
& \mathrm{AP}=\operatorname{AEQ}\left(\left\{p_{t}^{0}\right\},\left\{\gamma_{t}^{0}\right\}, W^{1}, W_{\max }^{1}\right)-\operatorname{AEQ}\left(\left\{p_{t}^{0}\right\},\left\{\gamma_{t}^{0}\right\}, W^{0}, W_{\max }^{0}\right), \\
& \mathrm{RP}=\operatorname{REQ}\left(\left\{p_{t}^{0}\right\},\left\{\gamma_{t}^{0}\right\}, W^{1}, W_{\max }^{1}\right)-\operatorname{REQ}\left(\left\{p_{t}^{0}\right\},\left\{\gamma_{t}^{0}\right\}, W^{0}, W_{\max }^{0}\right) .
\end{aligned}
$$

7Jorgenson et al. (2017, Chapter 3), Eq. (3.77). 


\subsection{Implementing carbon prices and revenue recycling}

The policies in EMF32 call for recycling carbon tax revenues using (1) lump sum rebates to households, (2) cutting capital tax rates, or (3) cutting labor tax rates. To implement a lump sum rebate that is proportional to household expenditures we rewrite dynasty $d$ 's expenditure (Eq. (9)) by adding the total rebate (TLUMP) to national full expenditures $\left(M_{t}\right)$.

$$
\bar{M}_{d t}^{\text {propor }}=\mu_{d t}^{0}\left(M_{t}+\text { TLUMP }\right) .
$$

If the rebate is given equally per capita, the dynasty expenditures is

$$
\bar{M}_{d t}^{\text {percap }}=\mu_{d t}^{0} M_{t}+\frac{\mathrm{nm}_{d}}{n_{t}^{\text {pop }}} \mathrm{TLUMP}^{8},
$$

where $\mathrm{nm}_{d}$ is the mean number of members in household of type $d$ and $n_{t}^{\text {pop }}$ is the total population (Jorgenson et al., 2017, Eqs. (3.93)-(3.95)). In the EMF 32 experiments, we adopted the "head tax" approach in (22). If revenue is recycled by cutting capital or labor taxes, this will be reflected in different disposable incomes, and hence different values of aggregate full expenditures, $M_{t}$.

\subsection{Per capita welfare and distribution}

We now extend IGEM's detail on household welfare, decomposing to the level of individuals. We portray the distributional effects of policy by first ranking the 244 household types in order of their full wealth. Equations (9) and (22) give the average $M_{d t}$ for each type depending on the scenario. Equation (6) gives the lifetime utility, $V_{d}$, and $\Omega_{d}\left(\left\{p_{t}\right\},\left\{\gamma_{t}\right\}, V_{d}\right)$ gives the full wealth of dynasty $d$ (the money measure of $V_{d}$, Eq. (11)). Our demographic groups are cross classified by the number of adults and children and this gives us the number of household members, $\mathrm{nm}_{d}$. We calculate the full wealth per capita by dividing household full wealth in the base and policy cases by family size in each of the 244 household groups $\left(\Omega_{d}^{\mathrm{pc}}=\Omega_{d} / \mathrm{nm}_{d}\right)$. These data are reweighted by the population of individuals as opposed to households, and then ordered, yielding a quintile distribution of per capita full wealth and EV's in terms of dollars and percentage change from the base case. ${ }^{9}$

Mean full wealth per capita ranges from $\$ 850,000$ in 2010 dollars for a 1-adult, 3+ children, nonwhite female headed, rural South household to $\$ 10.3$ million for a 2-adult, no children, white female headed, rural Northeast household, for a base case starting in 2015. These are our average "poorest" and "richest" individuals. The

\footnotetext{
${ }^{8}$ In IGEM, a lump-sum redistribution is implemented by adjusting the average tax rate on labor income holding the marginal rate unchanged, that is, leaving the price of leisure unchanged.

${ }^{9}$ Note that this method does not fully rank all the 1000s of households in the CEX sample by per capita wealth; we are using only the averages of the 244 types of households to rank these 244 groups. We are using, however, the detailed consumption information for the 244 types, not just the consumption information by quintile.
} 
population-weighted average mean full wealth for individuals is $\$ 4.9$ million, while the averages at half and twice mean full wealth are $\$ 2.4$ and $\$ 9.7$ million, respectively. Since these estimates are derived from household types, the quintile boundaries for individuals are not exact. Quintile 1 covers $20.1 \%$ of all individuals residing in $12.3 \%$ of all households and accounting for $10.5 \%$ of total mean full wealth. Quintile 5 covers $19.6 \%$ of all individuals residing in $26.5 \%$ of all households and accounting for $29.7 \%$ of total mean full wealth. For quintiles 2, 3, and 4, the corresponding numbers for individual quintile, household share and national wealth share are: $20.0 \%, 12.4 \%$ and $15.0 \%, 20.2 \%, 17.5 \%$ and $19.7 \%$, and $20.1 \%, 31.3 \%$, and $25.1 \%$, respectively. These estimates clearly show stark differences in per capita receipts if the compensation policy were equal lump sum payments to households instead of individuals. Let the ordered list of increasing per capita full wealth be denoted by $\Omega_{o(d)}^{\mathrm{pc}}, o(d)=1,2, \ldots, 244$.

The total full wealth of the ordered group $o(d)$ is the mean wealth multiplied by the number of households in that group, $\Omega_{o(d)}^{\text {tot }}=\Omega_{o(d)} * n f_{o(d)}$. Group d's share of total national full wealth $\left(\Omega^{\text {sum }}\right)$ is given by.

$$
\omega_{o(d)}^{\mathrm{tot}}=\Omega_{o(d)}^{\mathrm{tot}} / \Omega^{\mathrm{sum}}
$$

The equivalent variation for a policy for type $d$ dynasties is given by (11); we cumulate the EV's over all groups in each quintile. This allows us to show how some policies could have a positive EV for the lowest quintile while having a negative total EV for the country.

\section{Emissions Impacts}

We begin our discussion of the simulated impacts by describing the carbon tax rates and $\mathrm{CO}_{2}$ emission targets. Table 2 shows the cumulative $\mathrm{CO}_{2}$ emissions and their abatement from fossil fuel combustion in gigatonnes $\left(\mathrm{GtCO}_{2}\right)$ for the US economy. Over the period from 2015 through 2050, the extremes are easily identified. The \$25 @ $1 \%$ tax path secures emissions reductions in the range of $13 \%$ to $14 \%$ from base case levels. The high-tax trajectory — \$50@5\% - achieves abatement in the range of $31 \%$ to $32 \%$ from base case levels. In between, lie the outcomes for the \$25@5\% and $\$ 50 @ 1 \%$ tax paths. Cumulative emissions reductions in these scenarios are in the range of 40 to $44 \mathrm{GtCO}_{2}$, or $21 \%$ to $23 \%$, from base case levels.

Measuring cumulative emissions alone masks important issues of policy timing and duration. From Table 2, it appears that the \$25@5\% tax path is less effective than the $\$ 50$ @ $1 \%$ case in its abatement potential. The starting carbon price is lower, rises at a faster rate, but reaches a substantially higher steady-state level by 2050. While the period of interest ends in 2050, the carbon tax remains at its 2050 level in real terms forever. Since IGEM policy simulations span the years from 2015 to 2130 — with all variables in steady state by 2080 at the latest - there is significant abatement occurring after 2050. The two $1 \%$ growth scenarios secure post-2050 abatement that is more than two times greater than the figures reported for 2015-2050. For the two 5\% 
Table 2. Cumulative $\mathrm{CO}_{2}$ emissions from fossil fuel combustion: Gigatonnes $\mathrm{CO}_{2}\left(\mathrm{GtCO}_{2}\right)$, economy wide.

\begin{tabular}{lrrrc}
\hline Scenario title & \multicolumn{4}{c}{ Revenue recycling option } \\
\cline { 2 - 5 } & Lump sum & Capital & Labor & Lump sum \& capital \\
\hline Cumulative Emissions, 2015-2050 & & & & \\
Base Case & 194.4 & 194.4 & 194.4 & 194.4 \\
\$25 @ 1\% & 167.1 & 167.7 & 168.3 & - \\
\$25 @ 5\% & 152.8 & 153.7 & 154.0 & 153.1 \\
\$50 @ 1\% & 150.2 & 151.0 & 151.7 & - \\
\$50 @ 5\% & 131.9 & 133.0 & 133.2 & - \\
Cumulative Abatement, 2015-2050 & & & & \\
\$25 @ 1\% & 27.3 & 26.7 & 26.1 & - \\
\$25 @ 5\% & 41.6 & 40.7 & 40.4 & 41.3 \\
\$50 @ 1\% & 44.2 & 43.4 & 42.7 & - \\
\$50 @ 5\% & 62.5 & 61.4 & 61.2 & - \\
Cumulative Abatement, Post-2050 & & & & - \\
\$25 @ 1\% & 57.6 & 56.3 & 54.7 & - \\
\$25 @ 5\% & 136.5 & 134.0 & 131.3 & 135.3 \\
\$50 @ 1\% & 98.9 & 96.8 & 94.5 & - \\
\$50 @ 5\% & 202.3 & 199.4 & 197.0 & - \\
\hline
\end{tabular}

growth scenarios, post-2050 abatement is more than three times greater than the reported abatement from 2015 to 2050. Thus, in the longer run, the \$25 @ 5\% tax path achieves emissions reductions that exceed those from the $\$ 50 @ 1 \%$ tax regime. In observing IGEM, abatement is obtained more easily under high carbon prices in the earlier years than in the later years but, nevertheless, abatement occurs in all years under all prices.

The issue of international leakage is a matter of importance in assessing carbon tax policy, especially if the US is assumed to act unilaterally. A single-country model like IGEM with no endogenous world prices has only a limited ability to describe the trade impacts. With the assumed exogenous current account deficits and foreign debt fixed at base case levels, the terms of trade adjust as export supplies and import demands respond to the effects of carbon taxation and revenue recycling. In general equilibrium, prices are passed through to all buyers and are influenced only by the carbon taxrevenue recycling pairing since there are no border controls. While we can compute the change in carbon embodied in the U.S. trade flows, we cannot account for changes in emissions in the rest-of-the-world. Under all tax paths and recycling schemes, the exports of coal, oil and gas decline as well as those of electricity. The imports of coal, oil and gas also decline under all pairings since they are also subject to the carbon price. The small imports of electricity rise in these cases since they are not subject to a carbon price; however, we do not know the generation mix supporting these electricity imports.

As for nonenergy trade patterns, the revenue recycling scheme matters. Under lump sum redistribution, all nonenergy exports decline except those of educational services 
which rise slightly. All nonenergy imports decline without exception. Nonenergy imports also decline under the capital and labor tax swaps with the exceptions of agriculture and food imports under labor tax recycling. The nonenergy export story is more varied. Under capital tax recycling, export increases occur in fabricated metals, IT, electrical and transportation equipment, miscellaneous manufacturing, printing, wholesale trade and all of the service commodities with the exceptions accommodations and other government; other nonenergy exports decline. With the labor tax option, export increases occur in all commodities except those from the energyintensive sectors like mining, nonmetals, wood and paper, primary metals, machinery, motor vehicles, chemicals and transportation. As with energy, the impacts of these altered trade patterns on global emissions are not determinable in IGEM.

While international carbon leakage is of potential importance in the unilateral design of climate change policy, there is a domestic concern that receives little attention. In IGEM over the period 2010-2050, the $\mathrm{CO}_{2}$ equivalent emissions from fossil fuel combustion account for only $93 \%$ of total $\mathrm{CO}_{2}$ emissions and only $74 \%$ of all GHG emissions. By only taxing the emissions from fossil fuel combustion, there is the possibility of offsetting increases in $\mathrm{CO}_{2}$ and other GHG emissions unrelated to combustion. Fortunately, this does not occur in IGEM since many of the sources of these other emissions are also major energy users - cement, chemicals, metals,

Table 3. Abatement spillovers (negative domestic leakage): Million metric tonnes $\mathrm{CO}_{2}$ equivalent $\left(\mathrm{mmtCO}_{2}-\mathrm{e}\right)$.

\begin{tabular}{|c|c|c|c|c|}
\hline & 2020 & 2030 & 2040 & 2050 \\
\hline \multicolumn{5}{|l|}{$\$ 25 @ 5 \%$} \\
\hline \multicolumn{5}{|l|}{ Abatement, Lump Sum } \\
\hline Change in noncombustion $\mathrm{CO}_{2}$ emissions & -17.3 & -24.3 & -34.2 & -46.8 \\
\hline $\begin{array}{l}\text { Change in } \operatorname{nonCO}_{2} \text { GHG emissions } \\
\text { Abatement, Capital Tax }\end{array}$ & -44.7 & -62.1 & -82.5 & -107.3 \\
\hline Change in noncombustion $\mathrm{CO}_{2}$ emissions & -13.2 & -18.9 & -27.3 & -39.6 \\
\hline $\begin{array}{l}\text { Change in } \text { nonCO }_{2} \text { GHG emissions } \\
\text { Abatement, Labor Tax }\end{array}$ & -38.9 & -50.3 & -66.7 & -90.3 \\
\hline Change in noncombustion $\mathrm{CO}_{2}$ emissions & -14.3 & -19.0 & -27.6 & -36.1 \\
\hline Change in nonCO $\mathrm{C}_{2} \mathrm{GHG}$ emissions & -39.6 & -44.3 & -57.7 & -73.4 \\
\hline \multicolumn{5}{|l|}{$\$ 50 @ 5 \%$} \\
\hline Change in noncombustion $\mathrm{CO}_{2}$ emissions & -30.7 & -42.1 & -57.6 & -76.6 \\
\hline $\begin{array}{l}\text { Change in } \text { nonCO }_{2} \text { GHG emissions } \\
\text { Abatement, Capital Tax }\end{array}$ & -74.6 & -102.7 & -134.0 & -170.0 \\
\hline Change in noncombustion $\mathrm{CO}_{2}$ emissions & -24.0 & -33.9 & -47.4 & -66.1 \\
\hline $\begin{array}{l}\text { Change in nonCO } \mathrm{C}_{2} \text { GHG emissions } \\
\text { Abatement, Labor Tax }\end{array}$ & -64.9 & -84.1 & -109.9 & -144.6 \\
\hline Change in noncombustion $\mathrm{CO}_{2}$ emissions & -25.6 & -33.7 & -47.6 & -61.9 \\
\hline Change in nonCO $\mathrm{C}_{2} \mathrm{GHG}$ emissions & -66.1 & -73.2 & -94.1 & -119.3 \\
\hline
\end{tabular}


mining. Under all carbon tax and recycling pairings, there occur additional net reductions in both noncombustion $\mathrm{CO}_{2}$ and $\mathrm{GHG}$ emissions. This additional abatement is shown in Table 3 for the \$25@5\% and \$50@5\% carbon tax paths. Clearly, there is a positive domestic spillover, i.e., negative domestic leakage, in emissions abatement from the more limited taxation of carbon.

\section{Economic Impacts}

We next examine the economic impacts of carbon taxes by considering the average adjustments of economic activity over the period 2015-2050.The driving force behind these changes is that prices rise for almost all commodity groups relative to the leisure price numeraire. Market participants must adjust to these higher prices. However, the adjustments differ substantially among the different methods for utilizing the tax revenues.

We present the impacts of alternative carbon policies on prices relative to the labor price numeraire in Tables 4 and 5. Table 4 shows the effects of the four core tax regimes on commodity supply prices under lump-sum redistributions of tax revenues. Table 5 shows these outcomes for the $\$ 25 @ 5 \%$ tax trajectory for the three recycling scenarios.

\subsection{Lump-sum recycling}

Energy prices - coal, oil, gas, and electricity — are strongly affected by carbon taxes with the greatest impact on coal prices. This is not surprising in that $74 \%$ of greenhouse gas emissions over 2015-2050 are fossil-fuel-related - the use of coal (20\%), refined petroleum (31\%), and gas (23\%); fossil fuels in electricity production alone account for $26 \%$. Coal, with the highest carbon content among the fossil fuels, and gas use in the generation of electricity primarily account for the shock to electricity prices.

We assume that the stock of capital (which includes land and resources) is fixed in the oil and gas mining sectors. This leads to upward sloping oil and gas supply curves. With the reduced demand for crude from petroleum refining, the output of this sector falls, thus lowering prices for domestic crude oil extraction. In gas mining, this demand-supply effect on prices is more than offset by the incidence of carbon taxes on the direct purchases of gas mining output by industry and electric utilities.

All nonenergy prices increase under lump-sum recycling. The heavy users of fossil fuel energy and electricity are affected most - agriculture, nonenergy mining, the nonmetals and metals commodities, machinery, motor vehicles, food, textiles and apparel, chemicals, and transportation. Other sectors and particularly the services commodities are much less affected.

We next consider the impacts of price changes on economic performance. Table 6 shows the impacts on final demand (GDP) and its components, while Table 7 presents the outcomes for the capital stock, labor demand and supply, leisure demand and full consumption. These tables summarize all four tax scenarios and all three recycling 
Table 4. Impacts on commodity prices for different tax levels (lump sum redistribution): Average percent change from base, 2015-2050.

\begin{tabular}{|c|c|c|c|c|}
\hline Lump sum redistribution & $\$ 25 @ 1 \%$ & $\$ 25 @ 5 \%$ & $\$ 50 @ 1 \%$ & $\$ 50 @ 5 \%$ \\
\hline Agriculture & 0.66 & 1.13 & 1.24 & 2.04 \\
\hline Oil mining & -1.05 & -1.88 & -2.00 & -3.38 \\
\hline Gas mining & 1.59 & 2.85 & 2.99 & 5.02 \\
\hline Coal mining & 20.58 & 32.33 & 36.54 & 55.18 \\
\hline Nonenergy mining & 0.82 & 1.44 & 1.55 & 2.65 \\
\hline Electric utilities & 7.01 & 11.64 & 12.56 & 19.91 \\
\hline Gas utilities & 5.91 & 11.18 & 11.88 & 22.43 \\
\hline Water and wastewater & 0.37 & 0.61 & 0.69 & 1.07 \\
\hline Construction & 0.43 & 0.72 & 0.80 & 1.32 \\
\hline Wood and paper & 0.83 & 1.43 & 1.54 & 2.59 \\
\hline Nonmetal mineral products & 1.06 & 1.85 & 2.00 & 3.41 \\
\hline Primary metals & 1.11 & 1.92 & 2.08 & 3.51 \\
\hline Fabricated metal products & 0.58 & 0.95 & 1.07 & 1.69 \\
\hline Machinery & 0.59 & 1.00 & 1.08 & 1.75 \\
\hline Information technology equipment & 0.47 & 0.79 & 0.84 & 1.33 \\
\hline Electrical equipment & 0.49 & 0.82 & 0.88 & 1.41 \\
\hline Motor vehicles and parts & 0.58 & 0.99 & 1.06 & 1.72 \\
\hline Other transportation equipment & 0.47 & 0.78 & 0.85 & 1.36 \\
\hline Miscellaneous manufacturing & 0.47 & 0.80 & 0.85 & 1.38 \\
\hline Food, beverage and tobacco & 0.65 & 1.10 & 1.20 & 1.97 \\
\hline Textiles, apparel and leather & 0.57 & 0.96 & 1.01 & 1.63 \\
\hline Printing and related activities & 0.43 & 0.70 & 0.79 & 1.25 \\
\hline Petroleum and coal products & 5.00 & 8.89 & 9.70 & 16.87 \\
\hline Chemicals, rubber and plastics & 0.65 & 1.11 & 1.21 & 1.98 \\
\hline Wholesale trade & 0.32 & 0.52 & 0.58 & 0.91 \\
\hline Retail trade & 0.34 & 0.55 & 0.62 & 0.95 \\
\hline Transportation and warehousing & 1.40 & 2.45 & 2.68 & 4.55 \\
\hline Publishing, broadcasting, telecommunications & 0.34 & 0.55 & 0.62 & 0.95 \\
\hline Software \& information technology services & 0.33 & 0.54 & 0.60 & 0.93 \\
\hline Finance and insurance & 0.33 & 0.53 & 0.60 & 0.91 \\
\hline Real estate and leasing & 0.46 & 0.71 & 0.82 & 1.23 \\
\hline Business services & 0.25 & 0.40 & 0.46 & 0.70 \\
\hline Educational services & 0.32 & 0.53 & 0.59 & 0.94 \\
\hline Health care and social assistance & 0.31 & 0.51 & 0.57 & 0.89 \\
\hline Accommodation and other services & 0.38 & 0.62 & 0.69 & 1.08 \\
\hline Other government & 0.31 & 0.52 & 0.59 & 0.95 \\
\hline
\end{tabular}

options; we first discuss lump-sum redistributions, then discuss the capital and labor recycling options.

Among the combinations of carbon-tax levels and fiscal reforms, lump-sum redistributions result in the largest negative impact on both the demand and supply sides of the US economy. Losses in GDP from base-case levels, averaged over 2015-2050, range from just under $0.7 \%$ to around $2.0 \%$ as carbon-tax rates increase. 
Table 5. Impacts on commodity prices for different recycling options ( $\$ 25 @ 5 \%$ case): Average percent change from base, 2015-2050.

\begin{tabular}{lrrr}
\hline \$25 @ 5\% under recycling option & Lump sum & Capital tax & Labor tax \\
\hline Agriculture & 1.13 & 0.44 & -0.77 \\
Oil mining & -1.88 & -1.89 & -3.44 \\
Gas mining & 2.85 & 2.85 & 1.51 \\
Coal mining & 32.33 & 31.14 & 30.21 \\
Nonenergy mining & 1.44 & 0.88 & -0.53 \\
Electric utilities & 11.64 & 10.89 & 9.79 \\
Gas utilities & 11.18 & 10.63 & 9.51 \\
Water and wastewater & 0.61 & -0.10 & -1.34 \\
Construction & 0.72 & 0.38 & -1.40 \\
Wood and paper & 1.43 & 0.89 & -0.57 \\
Nonmetal mineral products & 1.85 & 1.44 & -0.20 \\
Primary metals & 1.92 & 1.55 & -0.13 \\
Fabricated metal products & 0.95 & 0.51 & -1.09 \\
Machinery & 1.00 & 0.53 & -1.01 \\
Information technology equipment & 0.79 & 0.45 & -1.27 \\
Electrical equipment & 0.82 & 0.44 & -1.22 \\
Motor vehicles and parts & 0.99 & 0.67 & -1.08 \\
Other transportation equipment & 0.78 & 0.33 & -1.28 \\
Miscellaneous manufacturing & 0.80 & 0.42 & -1.26 \\
Food, beverage and tobacco & 1.10 & 0.51 & -0.87 \\
Textiles, apparel and leather & 0.96 & 0.74 & -1.10 \\
Printing and related activities & 0.70 & 0.25 & -1.37 \\
Petroleum and coal products & 8.89 & 8.62 & 7.22 \\
Chemicals, rubber and plastics & 1.11 & 0.58 & -0.84 \\
Wholesale trade & 0.52 & -0.05 & -1.51 \\
Retail trade & 0.55 & 0.02 & -1.52 \\
Transportation and warehousing & 2.45 & 2.00 & 0.42 \\
Publishing, broadcasting, telecommunications & 0.55 & -0.19 & -1.38 \\
Software \& information technology services & 0.54 & 0.06 & -1.53 \\
Finance and insurance & 0.53 & -0.21 & -1.40 \\
Real estate and leasing & 0.71 & -0.35 & -1.03 \\
Business services & 0.40 & -0.08 & -1.66 \\
Educational services & 0.53 & 0.04 & -1.53 \\
Health care and social assistance & 0.51 & 0.03 & -1.56 \\
Accommodation and other services & 0.62 & 0.13 & -1.44 \\
Other government & 0.02 & -1.51 \\
\hline & & & \\
& 0.52 & & \\
& & & \\
& & &
\end{tabular}

Losses in consumer spending are smaller but in line with the GDP amounts while investment and the trade components experience more significant reductions.

The declines in investment adversely affect capital formation, and the fall in capital stock averages between $0.7 \%$ and $1.9 \%$, depending on the tax trajectory. The reduction in labor use averages from $0.5 \%$ to $1.3 \%$ as carbon tax regimes intensify. Opposing 
Table 6. Impacts on final demand quantities for different recycling options: Average percent change from base, 2015-2050.

\begin{tabular}{|c|c|c|c|}
\hline Under recycling option & Lump sum & Capital tax & Labor tax \\
\hline \multicolumn{4}{|l|}{ \$25@1\% } \\
\hline GDP & -0.68 & 0.07 & 0.17 \\
\hline Consumption & -0.60 & -0.25 & 0.36 \\
\hline Investment & -1.20 & 0.62 & -0.05 \\
\hline Government & 0.00 & 0.00 & 0.00 \\
\hline Exports & -1.40 & -0.18 & -0.58 \\
\hline Imports & -1.29 & -0.36 & -0.38 \\
\hline \multicolumn{4}{|l|}{$\$ 25 @ 5 \%$} \\
\hline GDP & -1.16 & 0.20 & -0.06 \\
\hline Consumption & -0.98 & -0.46 & 0.32 \\
\hline Investment & -2.14 & 1.32 & -0.78 \\
\hline Government & 0.00 & 0.00 & 0.00 \\
\hline Exports & -2.41 & -0.22 & -1.38 \\
\hline Imports & -2.34 & -0.65 & -1.15 \\
\hline \multicolumn{4}{|l|}{$\$ 50 @ 1 \%$} \\
\hline GDP & -1.25 & 0.03 & 0.20 \\
\hline Consumption & -1.11 & -0.54 & 0.53 \\
\hline Investment & -2.11 & 0.96 & -0.19 \\
\hline Government & 0.00 & 0.00 & 0.00 \\
\hline Exports & -2.56 & -0.49 & -1.20 \\
\hline Imports & -2.27 & -0.69 & -0.74 \\
\hline \multicolumn{4}{|l|}{$\$ 50 @ 5 \%$} \\
\hline GDP & -2.02 & 0.15 & -0.19 \\
\hline Consumption & -1.75 & -0.92 & 0.39 \\
\hline Investment & -3.50 & 1.98 & -1.24 \\
\hline Government & 0.00 & 0.00 & 0.00 \\
\hline Exports & -4.15 & -0.69 & -2.49 \\
\hline Imports & -3.84 & -1.18 & -1.93 \\
\hline
\end{tabular}

this, gains in leisure range from $0.2 \%$ to $0.5 \%$, depending on the tax path, and partially compensate households in terms of their full consumption.

The economic impacts of carbon taxes on the US economy are dominated by the decisions of households. Anticipating price increases from rising carbon taxes, households first shift full consumption from the future towards the present. This reduces saving and lowers the rate of capital formation. Next, since carbon taxes make consumer goods and services more expensive relative to leisure, households substitute leisure for goods and services. Consumption of goods and services declines because lower labor input leads to lower current and real incomes. Increased leisure improves household welfare while reducing personal consumption expenditures reduces it. Finally, personal consumption expenditures are redirected from goods and services with large price increases toward those with smaller price increases. Since household 
Table 7. Impacts on capital, labor, leisure and full consumption quantities for different recycling options: Average percent change from base, 2015-2050.

\begin{tabular}{lrrr}
\hline Under recycling option & Lump sum & Capital tax & Labor tax \\
\hline \$25 @ 1\% & & & \\
Capital stock & -0.74 & 0.49 & -0.18 \\
Labor demand and supply & -0.45 & -0.13 & 0.58 \\
Leisure demand & 0.18 & 0.05 & -0.23 \\
Full consumption & -0.06 & 0.01 & -0.05 \\
\$25 @ 5\% & & & \\
Capital stock & -1.16 & 0.94 & -0.67 \\
Labor demand and supply & -0.79 & -0.14 & 0.73 \\
Leisure demand & 0.32 & 0.05 & -0.29 \\
Full consumption & -0.09 & -0.01 & -0.12 \\
\$50 @ 1\% & & & \\
Capital stock & -1.31 & 0.77 & -0.39 \\
Labor demand and supply & -0.78 & -0.24 & 0.98 \\
Leisure demand & 0.32 & 0.10 & -0.40 \\
Full consumption & -0.13 & -0.01 & -0.12 \\
\$50 @ 5\% & & & \\
Capital stock & -1.91 & 1.45 & -1.08 \\
Labor demand and supply & -1.30 & -0.27 & 1.22 \\
Leisure demand & 0.53 & 0.10 & -0.49 \\
Full consumption & -0.19 & -0.07 & -0.25 \\
\hline
\end{tabular}

spending is a large fraction of final demand, the decisions of households influence the structure of real GDP and the domestic production activity that supports it.

The production side of the economy is affected adversely by the fall in labor and capital supply due to the carbon taxes. All industries eventually experience declines in output. Industries subject to the carbon tax are especially hard hit. The changes in industry output for the lump-sum case, averaged over 2015-2050, are given for selected tax paths in Table 8, and for the three recycling schemes in $\$ 25$ @ 5\% case in Table 9. Obviously, the energy sectors are affected most following the imposition of a carbon tax on fossil fuel combustion. Next most affected are the heavy users of fossil fuel energy and electricity - nonenergy mining, water treatment, construction, wood and paper, the nonmetals and metals commodities, machinery, motor vehicles, textiles and apparel, chemicals, and transportation. Other manufacturing and the services industries are less directly affected by price effects but more so by reduced incomes.

Producers are forced to raise prices to cover their increase in costs but substitutions from more costly energy toward relatively cheaper materials, labor, and capital inputs help to mitigate this.

The reduction in labor income from the households' reduced labor supply combines with lower capital income from businesses to yield a reduction in the nominal GDP. 
Table 8. Impacts on domestic output quantities for different tax levels (lump sum redistribution): Average percent change from base, 2015-2050.

\begin{tabular}{|c|c|c|c|c|}
\hline Lump sum redistribution & $\$ 25 @ 1 \%$ & $\$ 25 @ 5 \%$ & $\$ 50 @ 1 \%$ & $\$ 50 @ 5 \%$ \\
\hline Agriculture & -0.90 & -1.55 & -1.70 & -2.80 \\
\hline Oil mining & -2.63 & -4.47 & -4.86 & -7.87 \\
\hline Gas mining & -5.87 & -9.65 & -10.32 & -15.73 \\
\hline Coal mining & -16.33 & -23.66 & -25.20 & -33.82 \\
\hline Nonenergy mining & -1.60 & -2.76 & -2.79 & -4.55 \\
\hline Electric utilities & -4.73 & -7.65 & -8.18 & -12.43 \\
\hline Gas utilities & -4.94 & -8.65 & -9.24 & -15.38 \\
\hline Water and wastewater & -1.56 & -2.63 & -2.83 & -4.57 \\
\hline Construction & -1.02 & -1.82 & -1.79 & -3.00 \\
\hline Wood and paper & -1.47 & -2.56 & -2.71 & -4.51 \\
\hline Nonmetal mineral products & -2.20 & -3.86 & -4.04 & -6.76 \\
\hline Primary metals & -2.19 & -3.81 & -3.97 & -6.56 \\
\hline Fabricated metal products & -1.30 & -2.20 & -2.32 & -3.70 \\
\hline Machinery & -1.40 & -2.43 & -2.46 & -4.03 \\
\hline Information technology equipment & -0.76 & -1.32 & -1.33 & -2.18 \\
\hline Electrical equipment & -0.86 & -1.52 & -1.52 & -2.51 \\
\hline Motor vehicles and parts & -1.38 & -2.42 & -2.45 & -4.03 \\
\hline Other transportation equipment & -0.64 & -1.13 & -1.17 & -1.93 \\
\hline Miscellaneous manufacturing & -0.97 & -1.73 & -1.74 & -2.89 \\
\hline Food, beverage and tobacco & -0.63 & -1.07 & -1.17 & -1.92 \\
\hline Textiles, apparel and leather & -1.00 & -1.73 & -1.85 & -3.06 \\
\hline Printing and related activities & -0.44 & -0.72 & -0.81 & -1.23 \\
\hline Petroleum and coal products & -4.16 & -7.04 & -7.65 & -12.30 \\
\hline Chemicals, rubber and plastics & -1.17 & -2.01 & -2.16 & -3.54 \\
\hline Wholesale trade & -0.63 & -1.09 & -1.12 & -1.80 \\
\hline Retail trade & -0.75 & -1.30 & -1.34 & -2.16 \\
\hline Transportation and warehousing & -2.66 & -4.55 & -4.84 & -7.87 \\
\hline Publishing, broadcasting, telecommunications & -0.54 & -0.91 & -0.97 & -1.54 \\
\hline Software \& information technology services & -0.81 & -1.43 & -1.42 & -2.31 \\
\hline Finance and insurance & -0.59 & -0.99 & -1.08 & -1.71 \\
\hline Real estate and leasing & -0.82 & -1.32 & -1.46 & -2.18 \\
\hline Business services & -0.81 & -1.40 & -1.47 & -2.39 \\
\hline Educational services & 0.23 & 0.40 & 0.41 & 0.68 \\
\hline Health care and social assistance & -0.33 & -0.56 & -0.63 & -1.03 \\
\hline Accommodation and other services & -0.66 & -1.11 & -1.21 & -1.97 \\
\hline Other government & -0.05 & -0.09 & -0.09 & -0.17 \\
\hline
\end{tabular}

Personal consumption declines even with the lump-sum redistribution of tax revenues. Private saving also declines. The reduction in savings and higher prices for investment goods lead to a lower capital stock. Reduced capital and labor inputs limit the economy's output potential.

Our scenarios for recycling carbon tax revenues through lump-sum redistributions assume no change in the combined deficits and debt levels of governments or the levels 
Table 9. Impacts on domestic output quantities for different recycling options ( $\$ 25$ @ 5\% case): Average percent change from base, 2015-2050.

\begin{tabular}{lrrr}
\hline \$25 @ 5\% Under recycling option & Lump sum & Capital tax & Labor tax \\
\hline Agriculture & -1.55 & -0.77 & 0.01 \\
Oil mining & -4.47 & -4.16 & -3.82 \\
Gas mining & -9.65 & -9.36 & -9.19 \\
Coal mining & -23.66 & -22.15 & -23.26 \\
Nonenergy mining & -2.76 & 0.49 & -1.56 \\
Electric utilities & -7.65 & -7.16 & -6.64 \\
Gas utilities & -8.65 & -7.97 & -7.86 \\
Water and wastewater & -2.63 & -2.40 & -1.43 \\
Construction & -1.82 & 0.64 & -0.61 \\
Wood and paper & -2.56 & -0.91 & -1.41 \\
Nonmetal mineral products & -3.86 & -1.86 & -2.81 \\
Primary metals & -3.81 & -1.29 & -2.76 \\
Fabricated metal products & -2.20 & 0.13 & -1.06 \\
Machinery & -2.43 & 0.73 & -1.25 \\
Information technology equipment & -1.32 & 0.90 & -0.31 \\
Electrical equipment & -1.52 & 1.13 & -0.40 \\
Motor vehicles and parts & -2.42 & 0.46 & -1.15 \\
Other transportation equipment & -1.13 & 0.54 & -0.36 \\
Miscellaneous manufacturing & -1.73 & 1.05 & -0.34 \\
Food, beverage and tobacco & -1.07 & -0.77 & 0.69 \\
Textiles, apparel and leather & -1.73 & -0.87 & 0.13 \\
Printing and related activities & -0.72 & 0.32 & 0.47 \\
Petroleum and coal products & -7.04 & -6.49 & -6.10 \\
Chemicals, rubber and plastics & -2.01 & -0.36 & -0.73 \\
Wholesale trade & -1.09 & 0.48 & 0.47 \\
Retail trade & -1.30 & 0.36 & 0.49 \\
Transportation and warehousing & -4.55 & -3.37 & -3.33 \\
Publishing, broadcasting, telecommunications & -0.91 & 0.39 & 0.22 \\
Software \& information technology services & -1.43 & 0.89 & -0.29 \\
Finance and insurance & -0.99 & -0.19 & 0.18 \\
Real estate and leasing & -1.32 & 0.78 & -0.68 \\
Business services & -1.40 & -0.17 & -0.15 \\
Educational services & 0.40 & 0.37 & 0.76 \\
Health care and social assistance & -0.09 & -0.01 & 0.07 \\
Accommodation and other services & & & \\
Other government & -1.13 & 0.31 \\
\hline & -1.04 \\
\hline
\end{tabular}

of real government purchases. However, there is some minor crowding-out of private investment as the relative prices of goods and services to governments change.

The current account balance is maintained by the endogenous adjustment of the terms of trade, i.e., the real exchange rate. The prices of US-made goods rise relative to world prices under the effects of the carbon tax. Since we estimate the supplies of 
exports to be price-elastic, export volumes fall more than export prices rise and the value of exports declines.

The change in imports is more complicated in that we have both income and price effects. Lower real household income reduces lifetime consumption. Lower lifetime consumption and investment means lower aggregate demand for imported goods and services. Domestic goods not directly subject to the carbon tax still have prices rise relative to world prices, inducing a substitution toward imported varieties. Fossil fuel use is subject to the carbon tax and so their imports are indirectly taxed and demand falls.

The opposing income and price effects result in a reduction in aggregate import demand that is smaller than but aligned with the reduction in exports. To maintain the current account balance at base-case levels, market equilibrium requires a long-run depreciation of the exchange rate.

\subsection{Cutting taxes on capital and labor}

We now turn to revenue recycling through reductions in tax rates, beginning with those on capital. We again hold real government purchases, deficits, and debt at base-case levels. As before, carbon-tax policy raises prices to producers and consumers. Under the \$25@5\% carbon-tax trajectory, capital-tax rates average 10.5\% lower than in the base case over the period 2015-2050. In the \$50 @ 5\% trajectory, the corresponding reductions average $19.1 \%$.

Recycling carbon-tax revenues through lower tax rates on capital reduces the rental price of capital services and raises the returns on saving and investment and, hence, capital income. Referring to Tables 6 and 7, this policy favors capital formation over the consumption of goods and services while the higher relative price of labor input leads to lower labor demand and more leisure. Overall, the increased availability of capital helps insulate the US economy from higher prices.

The average GDP change is positive in the capital tax cut cases unlike the other recycling scenarios. There also is a noticeable partition between the $1 \%$ and $5 \%$ growth scenarios; GDP increases more with the higher carbon tax growth path.

We also note a change in the trade patterns under capital tax recycling. In comparison to lump sum redistribution, export and import reductions are smaller and they reverse with import reductions proportionally larger than export reductions. Thus, while GDP rises a bit, the fall in net imports generates a fall in consumption. With current account neutrality, there is little variation in nominal net exports across recycling schemes within a given carbon tax scenario. However, there is variation in the components of net exports. As domestic prices, commodity demands and the terms of trade vary from one recycling scheme to another, so too do the levels of exports and imports even though their difference is relatively unaffected.

Under the capital tax swap, we find in Table 9 a pattern of changes in industrial outputs that reflects both improved economic performance and the change in the 
investment/consumption ratio. Energy aside, capital tax recycling leads to increases in all things related to investment and capital accumulation. On average, the outputs of nonenergy mining, construction, finished metals, the equipment sectors, printing, trade, telecom, and software increase while those related to consumption - agriculture, food, apparel, health care and accommodations - decline.

We next consider the substitution of carbon taxes for labor taxes. The taxes levied on fossil fuel combustion emissions still raise prices to producers and consumers. The increases in carbon-tax revenues are returned to households through reductions in the average and marginal tax rates on labor income. For the \$25 @ 5\% carbon-tax trajectory, these rate reductions average 7.7\% from 2015-2050. The $\$ 50 @ 5 \%$ tax trajectory permits corresponding reductions averaging $13.0 \%$. For broadly similar carbon-tax revenues, the differences in tax bases and tax rates imply that proportional capital-tax reductions must be significantly larger than labor-tax reductions to achieve deficit neutrality.

The labor-tax rate reductions raise the opportunity cost of consuming leisure. As shown in Tables 6 and 7, households substitute toward consumption and away from leisure. With the numeraire as the leisure price, the changes in the labor-tax rate imply a lower labor input price to employers. Labor demand increases at a reduced pre-tax wage. Producers absorb this additional labor, restructuring inputs toward labor and away from emissions-generating activities and capital. Unit production costs and commodity prices in terms of the numeraire fall relative to the base case and the other recycling options. Falling commodity prices against the numeraire yield the rising real wage that incentivizes the demand-matching increase in labor supply.

Labor-tax rate reductions favor consumption over saving and investment. Income rises from greater labor supply, but this is more than offset by a decline in capital income due to a lower capital stock. Given the intertemporal preferences we have estimated and the time profile of real wages, the reduction in lifetime full income is optimized by having higher full consumption in the near term before the carbon tax is imposed and lower full consumption in the longer term. Higher full consumption in the near term combined with higher labor supply means higher goods consumption and reduced saving. Reduced saving leads to reductions in investment and a lower rate of capital formation even with lower prices for investment goods.

Again, there is a noticeable partition between the $1 \%$ and 5\% growth scenarios. The increases in consumption are larger and the decreases in investment are smaller in the $1 \%$ cases than they are in the 5\% cases. Moreover, GDP increases under the $1 \%$ growth rates but declines under the 5\% rates. The above results clearly suggest that the economy is more capital-sensitive than it is labor-sensitive to carbon tax policy.

The favorable price effects from labor-tax recycling at the commodity level, relative to the leisure price numeraire, are shown in Table 5. Under this scheme, we see price decreases for all nonenergy commodities except transportation which, of course, is fossil-fuel intensive. No other recycling option delivers this effect. 
Tables 6 and 7 show that labor-tax recycling promotes consumption over investment and labor over leisure. Full consumption declines in line with that observed under lump sum redistribution. However, the patterns of consumption and leisure are reversed - consumption increases and leisure decreases under labor tax recycling while consumption decreases and leisure increases in the lump sum case.

Under the labor tax option, the declines in investment are quite modest in comparison to lump-sum recycling and yield smaller declines in the capital stock. The effects on the components of trade also are smaller than under lump sum. In percentage terms, export reductions still exceed import reductions and do not reverse as they do under the capital tax option.

Finally, Table 9 shows the consumption bias that structurally occurs under labor tax recycling. Now, the industries that benefit from the carbon tax pairing are agriculture, food, apparel, printing, retail trade, finance, education, health care, and accommodations. The capital goods industries are less affected than under the lump sum treatment because investment and the overall economy are less affected but there is still a noticeable redirection away from them.

\section{Carbon Taxation and Policy Scoring}

Federal initiatives are examined through the lens of policy scoring. Such analysis considers the broad temporal consequences of potential enactment with emphasis on the policy's effects on tax revenue streams, programmatic spending, annual deficits and US indebtedness. By intent and design, we simulate IGEM under the assumptions of deficit and debt neutrality with tax swaps that maintain the annual, real purchases of goods and services by Federal, state and local governments at their base case levels. Accordingly, the scoring metrics for carbon taxation under these assumptions are the annual percentage of carbon tax revenues that are redistributed through reduced taxation elsewhere and its complement, the percentage required to hold government purchases unchanged. The latter is the so-called policy's "haircut". Formally, these are determined as follows.

Annual carbon tax revenues, CTR, cover changes between a policy case (denoted with a $P$ superscript), and the reference or base case (superscript $R$ ); changes in the deficit of governments (DEF), their expenditures (EXP), and their tax revenues from traditional, noncarbon sources (REV). Algebraically,

$$
\mathrm{CTR}=\left(\mathrm{DEF}^{R}-\mathrm{DEF}^{P}\right)+\left(\mathrm{EXP}^{P}-\mathrm{EXP}^{R}\right)-\left(\mathrm{REV}^{P}-\mathrm{REV}^{R}\right) .
$$

Under deficit neutrality, $\left(\mathrm{DEF}^{R}-\mathrm{DEF}^{P}\right)$ is zero. If, in any simulation involving tax swaps, it is not, then it becomes part of the haircut. However, DEF is not part of the haircut if the goal is to use carbon tax revenues to reduce government deficits and debt.

The change in government expenditures, $\left(\mathrm{EXP}^{P}-\mathrm{EXP}^{R}\right)$, covers price changes in government purchases of goods and services, the aggregate of which is constant in real terms under tax recycling. It also covers any endogenous changes in nonfinal demand 
outlays (e.g., interest payments on government debt, transfers). No matter the cause or amount, it is part of the haircut in simulations involving tax swaps. However, EXP is not part of the haircut if the goal is to use carbon tax revenues to increase government spending.

In IGEM, traditional tax revenues, REV, arise from a variety of sources, each involving a tax rate, trate, applied to a tax base, TBASE. The components of $\left(\mathrm{REV}^{P}-\mathrm{REV}^{R}\right)$ thus take the general form

$$
\left(\text { trate }^{P} \times \operatorname{TBASE}^{P}-\operatorname{trate}^{R} \times \mathrm{TBASE}^{R}\right) .
$$

This change in REV can be decomposed as ${ }^{10}$

$$
\left(\text { trate }^{P}-\operatorname{trate}^{R}\right) \times \mathrm{TBASE}^{P}+\operatorname{trate}^{R} \times\left(\mathrm{TBASE}^{P}-\mathrm{TBASE}^{R}\right) .
$$

When component tax rates remain unchanged (i.e., revenues are not recycled), (trate ${ }^{P}$ trate $\left.^{R}\right)$ is zero and there are only general equilibrium effects arising from changes in the tax base, $\left(\mathrm{TBASE}^{P}-\mathrm{TBASE}^{R}\right)$. These, like any change in DEF and EXP, are part of the haircut.

When component tax rates change (i.e., carbon revenues are recycled), (trate ${ }^{P}$ trate $^{R}$ ) is negative. ${ }^{11}$ There now are recycling effects in addition to general equilibrium tax consequences. Since the goal of recycling is to return as much of the carbon tax receipts as possible, the percentage recycled is given as

$$
\% \text { rec }=\left(\text { trate }^{P}-\text { trate }^{R}\right) \times \operatorname{TBASE}^{P} / \mathrm{CTR} .
$$

The haircut rate may thus be defined as

$$
\% \mathrm{~h}=1-\left(\operatorname{trate}^{P}-\operatorname{trate}^{R}\right) \times \operatorname{TBASE}^{P} / \mathrm{CTR} .
$$

Table 10 shows the percentages of carbon tax revenues redistributed through the various recycling mechanisms across the range of scenarios. The carbon-capital tax combination generally returns the greatest portion, in some early years even exceeding carbon receipts. The carbon-labor tax swap redistributes smaller portions than does the capital tax option for all but the $1 \%$ growth tax trajectories in the years between the mid-2020's and the early-2040's; here too there are years in which more money is redistributed than is raised by taxing carbon during the years when the GDP effect is positive. The percentage recycled is least and the haircut is greatest under lump sum redistribution, and by a substantial margin. This ranking follows from the pattern of output reductions observed for the three recycling options. In Sec. 4, we showed how the changes in production and spending from carbon taxation are least when capital taxes are reduced, and greatest when the revenues are returned to persons as lump sums.

\footnotetext{
${ }^{10}$ An alternative decomposition is given by $\left(\operatorname{trate}{ }^{P}-\operatorname{trate}^{R}\right) \times \operatorname{TBASE}^{R}+\operatorname{trate}^{P} \times\left(\mathrm{TBASE}^{P}-\mathrm{TBASE}^{R}\right)$ in which case the percentage recycled is $\left(\operatorname{trate}^{P}-\right.$-rate $\left.^{R}\right) \times \mathrm{TBASE}^{R} / \mathrm{CTR}$. These lack the intuitive appeal of 5.3.

${ }^{11}$ Lump-sum transfers are accomplished in IGEM in dollars through the variable TLUMP or by adjusting the average tax rate on labor income holding the marginal rate unchanged. For the same tax swap, e.g., recycling to preserve real government purchases at base case levels, the model solutions are identical. For lump-sum redistributions, the trate in the equations of this section refers to the average tax rate on labor income.
} 
Table 10. Recycled percentage of carbon tax revenues.

\begin{tabular}{lccccccc}
\hline & 2020 & 2025 & 2030 & 2035 & 2040 & 2045 & 2050 \\
\hline Lump sum redistribution & & & & & & & \\
\$25 @ 1\% & $72.4 \%$ & $66.8 \%$ & $64.0 \%$ & $62.2 \%$ & $61.8 \%$ & $62.3 \%$ & $63.2 \%$ \\
\$25 @ 5\% & $70.8 \%$ & $65.8 \%$ & $63.6 \%$ & $62.1 \%$ & $61.8 \%$ & $62.2 \%$ & $62.8 \%$ \\
\$50 @ 1\% & $71.2 \%$ & $65.9 \%$ & $63.5 \%$ & $62.0 \%$ & $61.9 \%$ & $62.5 \%$ & $63.3 \%$ \\
\$50 @ 5\% & $70.5 \%$ & $65.5 \%$ & $63.3 \%$ & $61.9 \%$ & $61.4 \%$ & $61.7 \%$ & $61.9 \%$ \\
Capital tax recycling & & & & & & & \\
\$25 @ 1\% & $100.8 \%$ & $99.0 \%$ & $96.7 \%$ & $94.0 \%$ & $92.2 \%$ & $91.4 \%$ & $90.5 \%$ \\
\$25 @ 5\% & $106.2 \%$ & $104.2 \%$ & $101.7 \%$ & $98.5 \%$ & $96.0 \%$ & $93.5 \%$ & $89.8 \%$ \\
\$50 @ 1\% & $99.6 \%$ & $97.2 \%$ & $94.8 \%$ & $92.3 \%$ & $90.9 \%$ & $90.4 \%$ & $89.8 \%$ \\
\$50 @ 5\% & $104.7 \%$ & $102.3 \%$ & $99.7 \%$ & $96.7 \%$ & $94.3 \%$ & $92.1 \%$ & $88.8 \%$ \\
Labor tax recycling & & & & & & & \\
\$25 @ 1\% & $92.7 \%$ & $102.6 \%$ & $101.3 \%$ & $97.5 \%$ & $93.6 \%$ & $90.2 \%$ & $88.5 \%$ \\
\$25 @ 5\% & $83.8 \%$ & $92.4 \%$ & $90.7 \%$ & $86.8 \%$ & $83.5 \%$ & $82.0 \%$ & $84.9 \%$ \\
\$50 @ 1\% & $91.3 \%$ & $100.9 \%$ & $99.7 \%$ & $96.0 \%$ & $92.1 \%$ & $89.0 \%$ & $87.2 \%$ \\
\$50 @ 5\% & $83.8 \%$ & $92.5 \%$ & $90.9 \%$ & $87.2 \%$ & $83.8 \%$ & $82.0 \%$ & $83.3 \%$ \\
\hline
\end{tabular}

In addition, with capital tax recycling, the capital tax base gets larger than in the no policy case while the labor tax base gets smaller. Under labor tax recycling, the opposite occurs. However, in the case of lump sum redistribution, there are no offsetting influences on these tax bases. Both the capital and labor tax bases shrink and, thus, a greater portion of carbon tax receipts must be used to restore the physical volume of government purchases than with either of the other two swap options.

There are other patterns worth noting in these results. Across the three recycling options, the percentages returned are larger and the haircuts smaller in the earlier years than they are in the later years under higher carbon taxes. As carbon prices rise, abatement becomes more difficult, the pressures on tax bases increase and more funds are required to preserve real government spending. Under lump sum redistribution, the percentages returned decline and haircuts increase through 2040 and then the trends slightly reverse. With capital tax recycling, there is no such reversal as there occur a systematic increase in the carbon tax haircut over time. For labor tax recycling, the pattern is mixed. Under the $1 \%$ growth scenarios, it is an inverted $\mathrm{U}$ with recycled percentages rising and haircuts falling and then reversing around the mid-2030s. For the $5 \%$ growth scenarios, the pattern is wave-like, following the inverted $U$ of the other labor tax scenarios but eventually reversing again and appearing like that observed under lump sum redistribution.

Finally, there are patterns associated with the levels and growth rates of carbon taxation. For a given growth rate, $1 \%$ or $5 \%$, it is generally the case that recycled percentages are larger and haircuts are smaller the lower the initial price, $\$ 25$ versus $\$ 50$, regardless of the recycling mechanism. Further, for a given initial price, $\$ 25$ or $\$ 50$, recycled percentages are larger and haircuts are smaller the lower the growth rate, 
$1 \%$ versus $5 \%$, but only under the lump sum and labor tax mechanisms; with capital tax recycling, it is the higher growth rate of 5\% that yields larger recycled percentages and smaller haircuts.

\section{Household and Individual Welfare}

\subsection{Household welfare}

In Sec. 2.3, we established the link between our model of consumer behavior and the measurement of household welfare. We calculate the welfare impact of carbon taxation as the equivalent variation in full wealth, i.e., how much full wealth must change at base-case prices to generate the same change in household welfare due to the carbon tax policy. We determine equivalent variations for the three possible levels of full wealth $\left(\Omega_{d}\right)$ for each household type - mean wealth, half the mean and twice the mean. Combining these three levels of full wealth with the 244 household types we have a total of 732 equivalent variations in response to each change in energy and environmental policy.

To summarize the changes in household full wealth for different demographic types, we compute population-weighted averages for each combination of the household characteristics. These are shown in Tables 11 for the \$25 @ 5\% carbon tax trajectory and the three revenue recycling options. The demographic conclusions from these are robust across the other carbon tax paths, differing only in scale. It is important not to misinterpret these summary household measures as indicators of social welfare.

Table 11. Household effects, \$25 @ 5\%, lump sum redistribution: Weighted-averages of household equivalent variations as a $\%$ of full wealth.

\begin{tabular}{lccc}
\hline & \multicolumn{3}{c}{ Full wealth } \\
\cline { 2 - 4 } & Mean & Half mean & Twice mean \\
\hline Lump sum redistribution & & & \\
Region of household & & & $-0.442 \%$ \\
Northeast & $-0.500 \%$ & $-0.557 \%$ & $-0.388 \%$ \\
Midwest & $-0.446 \%$ & $-0.504 \%$ & $-0.359 \%$ \\
South & $-0.417 \%$ & $-0.475 \%$ & $-0.451 \%$ \\
West & $-0.508 \%$ & $-0.566 \%$ & $-0.087 \%$ \\
Race \& gender of household head & & & $-0.405 \%$ \\
Nonwhite female & $-0.145 \%$ & $-0.203 \%$ & $-0.328 \%$ \\
White female & $-0.462 \%$ & $-0.520 \%$ & $-0.451 \%$ \\
Nonwhite male & $-0.386 \%$ & $-0.444 \%$ & $-0.416 \%$ \\
White male & $-0.509 \%$ & $-0.567 \%$ & $-0.226 \%$ \\
Location of household & & & $-0.401 \%$ \\
Urban & $-0.474 \%$ & $-0.532 \%$ & \\
Rural & $-0.284 \%$ & $-0.342 \%$ & $-0.517 \%$ \\
Overall & $-0.459 \%$ & & \\
\hline
\end{tabular}


Table 11. (Continued)

\begin{tabular}{|c|c|c|c|}
\hline & \multicolumn{3}{|c|}{ Full wealth } \\
\hline & Mean & Half mean & Twice mean \\
\hline \multicolumn{4}{|c|}{ Capital tax recycling } \\
\hline \multicolumn{4}{|c|}{ Region of household } \\
\hline Northeast & $-0.001 \%$ & $-0.033 \%$ & $0.032 \%$ \\
\hline Midwest & $-0.032 \%$ & $-0.065 \%$ & $0.000 \%$ \\
\hline South & $-0.043 \%$ & $-0.075 \%$ & $-0.010 \%$ \\
\hline West & $0.007 \%$ & $-0.026 \%$ & $0.039 \%$ \\
\hline \multicolumn{4}{|c|}{ Race \& gender of household head } \\
\hline Nonwhite female & $-0.025 \%$ & $-0.057 \%$ & $0.007 \%$ \\
\hline White female & $-0.030 \%$ & $-0.063 \%$ & $0.002 \%$ \\
\hline Nonwhite male & $-0.008 \%$ & $-0.040 \%$ & $0.025 \%$ \\
\hline White male & $-0.020 \%$ & $-0.053 \%$ & $0.012 \%$ \\
\hline \multicolumn{4}{|c|}{ Location of household } \\
\hline Urban & $-0.016 \%$ & $-0.048 \%$ & $0.016 \%$ \\
\hline Rural & $-0.089 \%$ & $-0.121 \%$ & $-0.056 \%$ \\
\hline Overall & $-0.022 \%$ & $-0.054 \%$ & $0.011 \%$ \\
\hline \multicolumn{4}{|c|}{ Labor tax recycling } \\
\hline \multicolumn{4}{|c|}{ Region of household } \\
\hline Northeast & $-0.155 \%$ & $-0.149 \%$ & $-0.161 \%$ \\
\hline Midwest & $-0.148 \%$ & $-0.142 \%$ & $-0.154 \%$ \\
\hline South & $-0.149 \%$ & $-0.143 \%$ & $-0.155 \%$ \\
\hline West & $-0.152 \%$ & $-0.147 \%$ & $-0.158 \%$ \\
\hline \multicolumn{4}{|c|}{ Race \& gender of household head } \\
\hline Nonwhite female & $-0.151 \%$ & $-0.145 \%$ & $-0.157 \%$ \\
\hline White female & $-0.123 \%$ & $-0.117 \%$ & $-0.129 \%$ \\
\hline Nonwhite male & $-0.181 \%$ & $-0.175 \%$ & $-0.186 \%$ \\
\hline White male & $-0.156 \%$ & $-0.150 \%$ & $-0.162 \%$ \\
\hline \multicolumn{4}{|c|}{ Location of household } \\
\hline Urban & $-0.150 \%$ & $-0.144 \%$ & $-0.156 \%$ \\
\hline Rural & $-0.156 \%$ & $-0.150 \%$ & $-0.161 \%$ \\
\hline Overall & $-0.151 \%$ & $-0.145 \%$ & $-0.157 \%$ \\
\hline
\end{tabular}

Over the entire set of 732 household types and incomes, the percentage changes in full wealth from taxing carbon are not large; with changes from lump sum redistribution being the largest, and those from capital tax recycling being the smallest. We find the variation in these percentage changes relative to their means to be greatest for the capital tax swap and least for labor tax recycling, with that for the lump sum option falling between. As evidence, the coefficient of variation across household types at the mean level of full wealth is 1.5 under capital tax recycling, 0.7 with lump sum redistribution and 0.2 for the labor tax swap.

The averages in each row provide insights into the regressivity or progressivity of the three revenue recycling schemes. For the lump sum and capital tax options, 
percentage losses diminish, and-or benefits increase, as full wealth increases. This suggests that these carbon tax swaps are, on average, regressive with respect to household full wealth within each household type. With labor tax recycling, the opposite occurs - average percentage losses rise with full wealth indicating its progressivity.

We next turn to region of residence and household location. With lump sum redistributions, percentage losses to households in the South are smallest followed by the Midwest, Northeast and West. It is not particularly surprising that the generally poorer regions of the country — the South and Midwest — fare better under lump sum recycling than do the wealthier Northeast and West. Consistent with this regional pattern, losses on average for urban households are considerably larger than they are for rural households. Under capital tax recycling, this pattern reverses although the magnitudes of change are significantly smaller. At mean full wealth, households in the West benefit slightly with a small average loss for those in the Northeast and much larger losses for those in the Midwest and South. Now, with lower capital taxation, it is the urban households that fare better than their rural counterparts. Under labor tax recycling, there appears a narrowing in the regional and urban-rural variation. Losses are least for households in the Midwest and South followed by the West and Northeast although, in percentage terms, the differences are not large. Urban households fare better than rural households by a similar spread.

Finally, for lump sum redistribution, households headed by females incur smaller percentage losses in full wealth than do households headed by males and households headed by nonwhites fare better than those headed by whites. Under the capital tax swap, the female-male ordering reverses but the nonwhite-white ranking remains the same; male-headed households experience the smaller losses as do households headed by nonwhites. With labor tax recycling, there is yet another ordering. Like lump sum, households headed by males suffer the larger percentage losses but now households headed by nonwhites are at a comparative disadvantage.

\subsection{Individual welfare}

Section 2.6 describes how we derive per-capita measures from the household level accounts. Table 12 shows the equivalent variations in individual lifetime full expenditure by quintile for the four carbon tax paths and the three recycling options. Also shown are the two tax swaps combining lump sum and capital redistribution for the \$25 @ 5\% scenario. The changes appear in both dollars and percentages, with lump sum the largest, capital recycling the smallest. As with the household averages discussed above, the spreads between the three recycling options are quite large.

The averages over individuals complicate the conclusions for regressivity and progressivity based on the household averages. Lump sum recycling is unambiguously progressive in both dollars and percentages. Indeed, the lowest quintile actually benefits under all carbon tax regimes. For the other quintiles, losses in dollars and as percentages of full wealth rise with rising affluence. These patterns also hold for the 


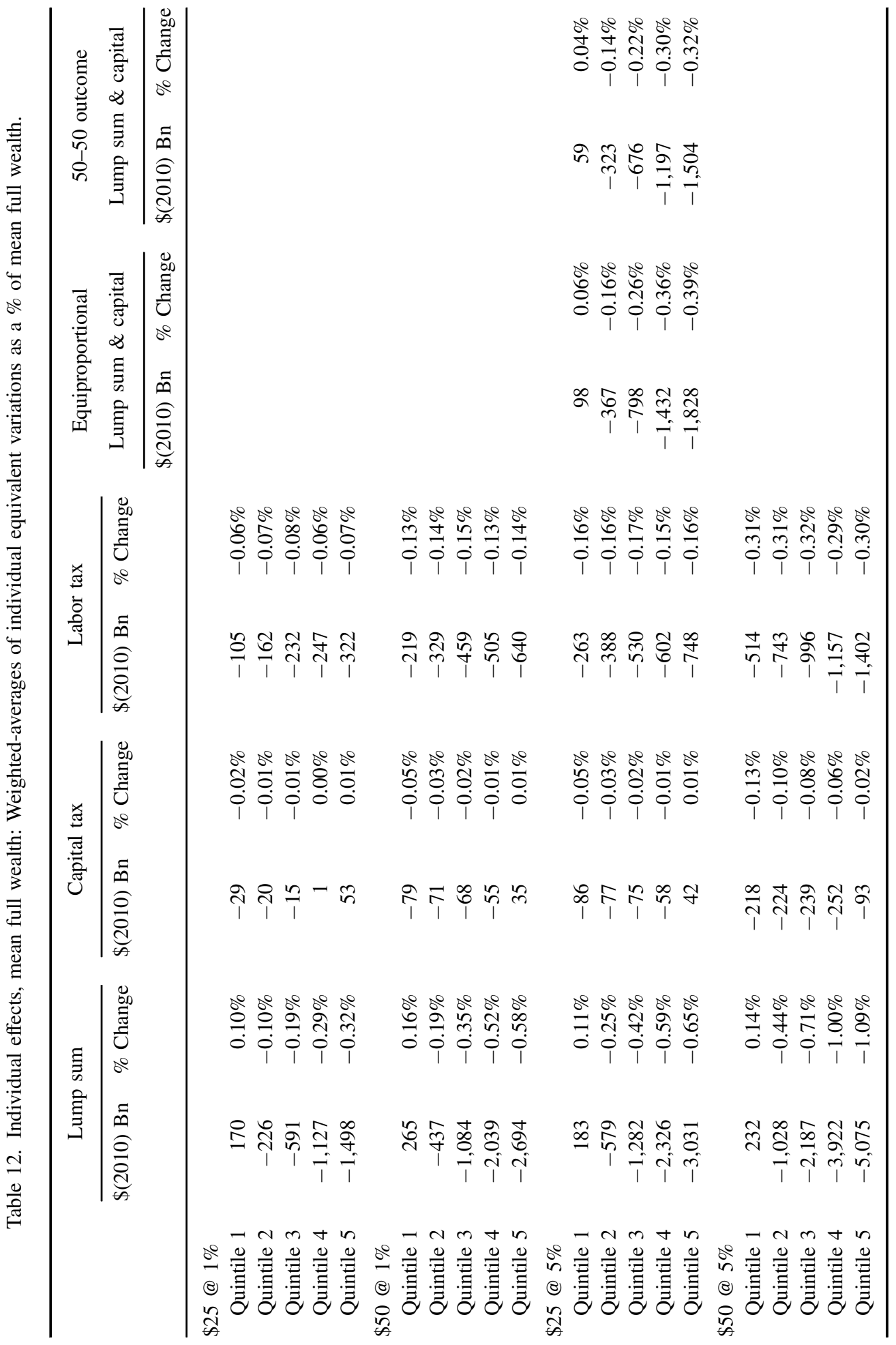


two blended options that include both lump sum transfers and capital tax cuts in the last four columns of Table 12. Purely reducing capital taxes is regressive in percentage terms with declining losses for each wealthier quintile. In dollar terms, it is regressive only in the lower carbon price cases, with small losses declining as wealth increases and small gains possible for the upper quintiles. However, as carbon taxation becomes more severe, we observe progressivity in the lower four quintiles; losses rise with rising wealth. It is only between quintiles four and five that we see regressivity. Labor tax recycling is progressive in dollar terms throughout the range of carbon tax paths. In percentage terms, however, it is progressive only through quintile three after which it regresses.

The quintile averages for individuals, like the household averages above, result from adding full wealth and equivalent variations in it. We again emphasize that these aggregations cannot be construed as either group or societal welfare because of the nature of preferences in IGEM's household utility model. We also note the need to reconcile differences in the findings on regressivity and progressivity between the household and individual averages. The filter that resolves these issues is our social welfare function and it is to this we now turn.

\section{Social Welfare Impacts}

In Sec. 2.4, we describe our money-metric measure of social welfare. Table 13 shows the equivalent variations in social welfare and their equity-efficiency decompositions for the twelve carbon tax-recycling option pairings under the purely egalitarian $(\mu=-1)$ and purely utilitarian $(\mu=-\infty)$ views. Unlike the household and individual averages in Sec. 6 where there are groups and persons who gained from the carbon policy, there are only welfare losses at the societal level under exact aggregation. There are losses in efficient welfare ( $W_{\max }$ in Eq. (13)) in all cases. The changes in the absolute values of equity welfare $(\triangle \mathrm{EQ})$ are smaller when society is least averse to inequality, i.e., under the purely utilitarian view.

Capital-tax rate recycling emerges as the clear winner in our social welfare comparisons. This option yields by far the smallest welfare burdens borne by society as its reductions of tax distortions more fully compensate the economic costs of carbon taxes. While its comparative advantage diminishes with increasingly aggressive carbon-tax structures, it has a very small loss under the low carbon price regimes. The major disadvantage of incentivizing new capital formation is its regressivity. The capital tax swap is regressive in the relative sense under all carbon tax paths. Like the quintile averages in Sec. 6, it is also regressive in the absolute sense until the rates of carbon taxation reach their highest levels. At this point, there is not only an erosion in capital tax's comparative advantage but also a transition to its becoming progressive in the absolute sense.

Labor-tax recycling is progressive in both the absolute and relative senses under both the egalitarian and utilitarian views. Losses in social welfare are much larger than 
Table 13. Social welfare effects: Welfare changes in \$(2010) billions.

\begin{tabular}{|c|c|c|c|c|c|c|}
\hline & \multicolumn{3}{|c|}{ Egalitarian } & \multicolumn{3}{|c|}{ Utilitarian } \\
\hline & Lump sum & $\begin{array}{c}\text { Capital } \\
\text { tax rate }\end{array}$ & $\begin{array}{l}\text { Labor } \\
\text { tax rates }\end{array}$ & $\begin{array}{l}\text { Lump } \\
\text { sum }\end{array}$ & $\begin{array}{l}\text { Capital } \\
\text { tax rate }\end{array}$ & $\begin{array}{c}\text { Labor } \\
\text { tax rates }\end{array}$ \\
\hline \multicolumn{7}{|l|}{$\$ 25 @ 1 \%$} \\
\hline Due to equity & $\$ 695$ & $-\$ 26$ & $\$ 409$ & $\$ 244$ & $-\$ 6$ & $\$ 174$ \\
\hline Due to efficiency & $-\$ 3,155$ & $-\$ 16$ & $-\$ 896$ & $-\$ 3,155$ & $-\$ 16$ & $-\$ 896$ \\
\hline Total & $-\$ 2,460$ & $-\$ 42$ & $-\$ 487$ & $-\$ 2,911$ & $-\$ 22$ & $-\$ 721$ \\
\hline \multicolumn{7}{|l|}{$\$ 50 @ 1 \%$} \\
\hline Due to equity & $\$ 1,253$ & $-\$ 21$ & $\$ 751$ & $\$ 436$ & $-\$ 4$ & $\$ 314$ \\
\hline Due to efficiency & $-\$ 5,780$ & $-\$ 243$ & $-\$ 1,840$ & $-\$ 5,780$ & $-\$ 243$ & $-\$ 1,840$ \\
\hline Total & $-\$ 4,527$ & $-\$ 264$ & $-\$ 1,089$ & $-\$ 5,344$ & $-\$ 247$ & $-\$ 1,526$ \\
\hline \multicolumn{7}{|l|}{ \$25@5\% } \\
\hline Due to equity & $\$ 1,445$ & $-\$ 17$ & $\$ 811$ & $\$ 496$ & $-\$ 1$ & $\$ 331$ \\
\hline Due to efficiency & $-\$ 6,780$ & $-\$ 257$ & $-\$ 2,206$ & $-\$ 6,780$ & $-\$ 257$ & $-\$ 2,206$ \\
\hline Total & $-\$ 5,335$ & $-\$ 274$ & $-\$ 1,395$ & $-\$ 6,284$ & $-\$ 258$ & $-\$ 1,875$ \\
\hline \multicolumn{7}{|c|}{ Indices of progressivity } \\
\hline Absolute & Progressive & Regressive & Progressive & Progressive & Regressive & Progressive \\
\hline Relative & Regressive & Regressive & Progressive & Regressive & Regressive & Progressive \\
\hline \multicolumn{7}{|l|}{$\$ 50 @ 5 \%$} \\
\hline Due to equity & $\$ 2,413$ & $\$ 53$ & $\$ 1,420$ & $\$ 821$ & $\$ 21$ & $\$ 568$ \\
\hline Due to efficiency & $-\$ 11,551$ & $-\$ 1,017$ & $-\$ 4,257$ & $-\$ 11,551$ & $-\$ 1,017$ & $-\$ 4,257$ \\
\hline Total & $-\$ 9,137$ & $-\$ 963$ & $-\$ 2,837$ & $-\$ 10,729$ & $-\$ 996$ & $-\$ 3,689$ \\
\hline \multicolumn{7}{|c|}{ Indices of progressivity } \\
\hline Absolute & Progressive & Progressive & Progressive & Progressive & Progressive & Progressive \\
\hline Relative & Regressive & Regressive & Progressive & Regressive & Regressive & Progressive \\
\hline
\end{tabular}

those under the capital tax option due to the labor tax bias against saving and investment and the increased willingness of households and individuals to sacrifice leisure prompted by real-wage incentives. Also, less of the carbon tax receipts are recycled under this scheme as compared to capital tax recycling.

Lump-sum redistribution results in the largest social welfare losses among the three swap options. Under this pairing, the economic impacts of carbon taxation are large and nonoffsetting for labor and capital. Consequently, the policy haircut is the largest. With only income effects and no relative price effects like those found under capital or labor tax recycling, the increases in leisure are insufficient compensation for the greater economic losses. Lump sum redistribution provides the largest gains in equity welfare and is progressive in the absolute sense under all carbon tax regimes and in both egalitarian and utilitarian views. This matches the conclusion from the quintile analysis of individuals. However, lump sum recycling is socially regressive in the relative sense under these same regimes and equity views. The improvements in equality, large as 


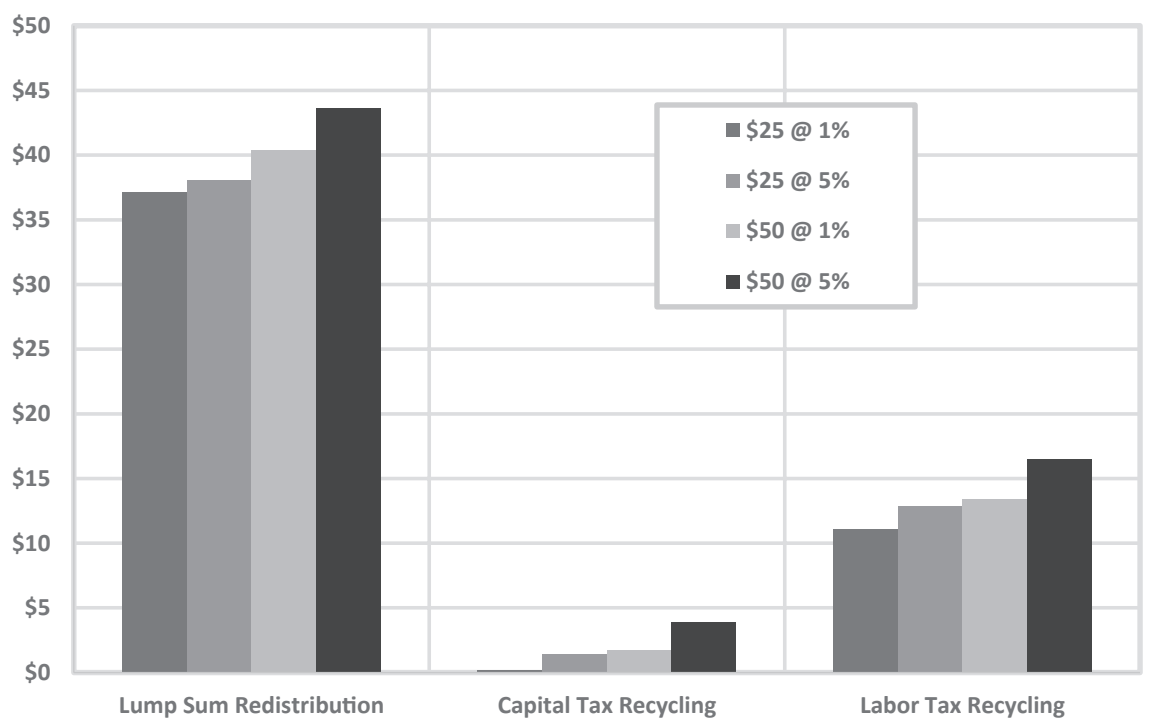

Figure 1. The welfare cost of abatement, $\$(2010)$ per $\mathrm{mtCO}_{2}-\mathrm{e}$

they are, are not enough to improve society's relative welfare ranking because they do not compensate the large losses in welfare efficiency.

As further evidence of the capital tax advantage, Fig. 1 shows the loss in efficient welfare, expressed as a welfare cost, per unit of cumulative abatement from 20152130. For the four tax-and-growth scenarios, the welfare cost of abatement ranges from $\$ 0.19$ to $\$ 3.90$ per ton with capital tax recycling. For labor tax recycling, the range is $\$ 11.09$ to $\$ 16.49$ per ton. With lump sum redistribution, the range is $\$ 37.15-\$ 43.61$ per ton. Across the four carbon tax paths, the per ton welfare costs of abatement under capital tax recycling average only $4.4 \%$ of those under lump sum recycling and only $12.4 \%$ of those under the labor tax option. Again, promoting capital formation is the best use of carbon tax revenues in terms of reducing the magnitudes of welfare losses while the lump sum and labor tax options are the best uses for reducing inequality.

The striking feature in the welfare results (Secs. 6 and 7) and in the macroeconomic results (Sec. 4) is the large spread among the three recycling options. Indeed, among the 10 CGE models participating in this phase of EMF 32, the spread appears greatest in IGEM. While unraveling the causes of this is beyond the scope of this paper, we believe there are three main reasons. First, is the heterogeneity, and magnitudes, of the elasticities arising from the more flexible functional form of IGEM's behavioral equations. In model comparisons, IGEM often appears more price responsive, especially in its labor-leisure tradeoff. Second, there are no restraints on the mobility of capital or labor beyond those embodied in IGEM's estimated parameters. Third, there are likely significant differences among the models in the manner in which tax incentives are structured. For example, in eight of the participating models, the distinctions between lump sum and labor tax recycling are small, suggesting similar 
incentive paths or very inelastic labor supplies. In IGEM, lump sum recycling involves only income effects while labor tax recycling involves both income and price effects.

There is no double dividend for social welfare among these scenarios. However, the conclusions above make clear the possibility of designing a carbon tax and revenue recycling scheme that holds the poorest harmless, is progressive to some extent for society, and results in small sacrifices in economic welfare to the benefit of the environment. Progressivity requires some combination of lump sum and labor tax recycling while reducing losses in social welfare requires more extensive use of the capital tax option.

\section{Contrast Between Bottom-Up and Top-Down Emissions Modeling}

As we note in Sec. 2.2, large scale multi-sector CGE models such as those used in the EMF studies almost always use a simplified single-market representation of the commodity markets. This abstracts from the fact, for example, that the coal price paid by the electricity sector is much lower than other buyers. In a one variety representation (Eq. (5)), a carbon price of $t x_{\mathrm{coal}, t}^{\mathrm{CO} 2}$ per unit of coal would result in an equal percentage increase in the coal input price for all consumers. We call this system "topdown emissions modeling". In IGEM, we use a "bottom-up" system where we recognize the different prices paid (Eq. (3)) and the carbon price $t x_{\text {coal }, t}^{\mathrm{CO} 2}$ results in different percentage changes in input prices for different purchasers. Similar issues arise with the pricing and uses of gas and oil.

In bottom-up emissions modeling, we not only can account for differences in pricing but also can isolate taxable uses even if commodities are of the one-price, homogeneous variety. In top-down emissions modeling, all buyers face an economywide average carbon price and homogeneity extends to emissions. We illustrate these differences in Table 14 which shows the bottom-up and top-down emissions coefficients for IGEM's base simulation year, 2015.

To highlight the magnitude of the difference in the two approaches we repeated the \$25 @ 5\% scenario using top-down emissions modeling, that is, taxing the average unit of fossil fuels so that all purchasers suffer the same percentage change in prices. The impact on emissions and other key variables from the two approaches are compared in Table 15. We discuss only the impacts for the capital tax and labor tax recycling cases here.

We begin by focusing on the tax shifting that occurs under the top-down system. Reductions in overall coal use are comparable across the two approaches; however, the top-down approach imposes a lighter tax burden on the coal price paid by electric utilities but a heavier one on other users like primary metals. This causes smaller reductions in coal-based generation compared to the bottom-up approach but larger reductions in primary metals output. Under the top-down system, the primary metals sector faces a much higher burden on its comparatively less-elastic coal use and thus a much larger demand and output losses. Reductions in national petroleum use are smaller 
Table 14. Emissions coefficients, 2015: Metric tons of $\mathrm{CO}_{2}$ per thousand $\$(2005)$.

\begin{tabular}{lccc}
\hline Combustion source & Coal & Petroleum & Gas \\
\hline Bottom-up & & & \\
Residential (Household) & 0 & 11.30 & 5.86 \\
Commercial and Governments & 50.14 & 0.32 & 3.46 \\
Industrial & 9.40 & 3.24 & 8.23 \\
Transportation & 0 & 11.30 & 15.54 \\
Electric utilities & 146.19 & 14.75 & 28.55 \\
Top-down & & & \\
Coal mining and imports & 57.69 & & \\
Petroleum products and imports & & 4.79 & \\
Gas mining and imports & & & 4.13 \\
Natural gas distribution & & & 6.69 \\
\hline
\end{tabular}

Table 15. Comparing impacts using bottom-up versus top-down emissions modeling ( $\$ 25$ @ 5\% case).

\begin{tabular}{|c|c|c|c|c|}
\hline & \multicolumn{2}{|c|}{ Bottom-up modeling } & \multicolumn{2}{|c|}{ Top-down modeling } \\
\hline & Capital tax & Labor tax & Capital tax & Labor tax \\
\hline Cumulative abatement $\left(\mathrm{GtCO}_{2}, 2015-2050\right)$ & 40.7 & 40.4 & 21.8 & 22.0 \\
\hline \multicolumn{5}{|l|}{ Egalitarian welfare change, $\$(2010)$ Billions } \\
\hline Total & -274 & -1395 & 2134 & 798 \\
\hline Due to equity & -17 & 811 & -444 & 528 \\
\hline \multicolumn{5}{|l|}{ Average percent change from base, 2015-2050 } \\
\hline GDP & 0.20 & -0.06 & 0.46 & 0.05 \\
\hline Consumption & -0.46 & 0.32 & 0.14 & 1.01 \\
\hline Investment & 1.32 & -0.78 & 2.22 & -0.48 \\
\hline Exports & -0.22 & -1.38 & -1.01 & -2.52 \\
\hline Imports & -0.65 & -1.15 & 0.88 & 0.21 \\
\hline Gas mining & -9.36 & -9.19 & -7.93 & -7.75 \\
\hline Coal mining & -22.15 & -23.26 & -22.56 & -23.80 \\
\hline Electric utilities & -7.16 & -6.64 & -4.21 & -3.59 \\
\hline Gas utilities & -7.97 & -7.86 & -9.07 & -9.01 \\
\hline Petroleum refining & -6.49 & -6.10 & -5.06 & -4.60 \\
\hline Primary metals & -1.29 & -2.76 & -5.13 & -7.01 \\
\hline Chemicals, rubber and plastics & -0.36 & -0.73 & -0.74 & -1.31 \\
\hline Transportation and warehousing & -3.37 & -3.33 & -1.29 & -1.28 \\
\hline
\end{tabular}

under the top-down approach; some petroleum users bear heavier burdens while others bear lighter burdens than occur under bottom-up emissions accounting. For natural gas, the burdens are shifted not only within the mining and utility groups but also across them. Output reductions are smaller for gas mining but larger for gas utilities. 
In the case of the gas mining commodity, electric utilities face a lower gas price while all other buyers, including gas utilities, face a higher one. Similarly, some gas utility customers face higher prices and others lower prices than under the bottomup approach. The net effect is that the chemicals, rubber and plastics industries experience larger output reductions as their fuel input prices rise by more in the top-down system, while output losses in commercial transportation are smaller due to smaller cost shocks.

Under capital tax recycling, the change in coal mining output is $-22 \%$, similar to the bottom-up approach, but gas mining output is $-7.9 \%$ versus $-9.4 \%$, gas utilities is $-9.1 \%$ versus $-8.0 \%$, and petroleum output is $-5.1 \%$ versus $-6.5 \%$. The impact of electric utilities is most notable, $-4.2 \%$ versus $-7.2 \%$; that is, the coal and gas reductions in the bottom-up approach are borne more by electric utilities which get cheaper coal and gas, compared to the top-down approach where the other users of coal and gas bear a bigger share of the burden. Under labor tax recycling, the change in coal mining output is a similar $-23 \%$, while gas mining output is $-7.8 \%$ versus $-9.2 \%$, gas utilities is $-9.0 \%$ versus $-7.9 \%$, petroleum output is $-4.6 \%$ versus $-6.1 \%$, and electric utilities is $-3.6 \%$ versus $-6.6 \%$. The net effect of this change in tax burdens is that the cumulative abatement of $\mathrm{CO}_{2}$ emissions is only about $22 \mathrm{Gt}$ in the top-down approach compared to the more than $40 \mathrm{Gt}$ under bottom-up modeling.

In the capital tax recycling scenarios, the GDP change (over 2015-2050) is now $0.46 \%$ compared to $0.20 \%$; there is a bigger double dividend under the top-down approach. Consumption benefits as average losses of $0.46 \%$ in the bottom-up approach are now gains averaging $0.14 \%$. The impact on investment and capital formation is even more favorable leading to smaller reductions in labor supply, smaller increases in leisure demand and increases in full consumption. Perhaps, more important are differences in the terms-of-trade effects; in the bottom-up-capital-tax case, they deteriorate (the dollar weakens and import reductions exceed export reductions), while in the top-down system the terms-of-trade improve. The contrast for labor tax recycling is equally dramatic; GDP change is a positive $0.05 \%$ compared to a $-0.06 \%$ in the bottom-up approach. This consists of a bigger average gain in consumption (1.01\% versus $0.32 \%)$ and a smaller loss in investment $(0.48 \%$ versus $0.78 \%)$. The improvement in the terms-of-trade in the top-down labor tax recycling case is even bigger with export reductions almost twice those in the bottom-up case.

The change from bottom-up to top-down emissions modeling has a positive impact on social welfare since the total emissions reductions is much smaller. Using the egalitarian form, social welfare under capital tax recycling increases by $\$ 2,134$ billion versus a bottom-up loss of $\$ 274$ billion. The gain in efficiency is $\$ 2,835$ billion while the loss due to increased inequality is $\$ 427$ billion. Under labor tax recycling, social welfare rises by $\$ 798$ billion compared to a bottom-up loss of $\$ 1,395$ billion. Under the top-down approach, capital tax recycling is regressive in the absolute sense but progressive in the relative sense; with bottom-up modeling, it is regressive in both metrics. Labor tax recycling remains progressive in both senses under both emissions accounting systems. 
These results indicate that one should take great care to specify clearly the modeling assumptions about emissions accounting. A common average price approach understates the negative impacts by not recognizing that sectors that pay below (above) average prices in the actual economy suffer more (less) from a carbon tax. Under the carbon price paths specified by the EMF 32 scenarios, the two approaches result in very different levels of $\mathrm{CO} 2$ abatement and very different social welfare impacts. We leave it for future work to plot the different marginal cost curves.

\section{Summary and Conclusions}

For the Energy Modeling Forum's assessment of US policies on carbon taxation and revenue recycling (EMF 32), we applied a new version of our Intertemporal General Equilibrium Model (IGEM) based on the North American Industry Classification System (NAICS). We simulated the impacts arising from a broad range of carbon taxes and three revenue recycling options - lump sum redistributions, capital tax reductions, and labor tax cuts. We followed the path from the introduction of a carbon taxand-swap pairing to their effects on industry prices and quantities, and then considered their macroeconomic consequences from both the top-down and bottom-up emissions accounting perspectives. We offered a temporal view of the so-called "haircut" that arises from the general equilibrium consequences of a carbon-tax-and-swap pairing and limits the amount of revenues recyclable from the swap. Finally, we examined the welfare implications of these pairings for households, individuals, and society, the latter in terms of efficiency and equity.

In IGEM, we find $\mathrm{CO}_{2}$ emissions abatement increases at a decreasing rate both over time and with the increasing severity of carbon taxation. While the economic and welfare outcomes for the uses of carbon tax receipts vary greatly across the three recycling options, we find the consequences for energy and emissions reductions do not. This means that policy makers need not compromise their environmental objectives when designing carbon tax swap options.

Reducing capital taxes promotes new saving, investment and capital formation and is the preferred recycling mechanism. It favors the capital goods industries, results in the least damage to the overall economy, allows the largest percentages of carbon tax revenues to be recycled, and secures the smallest losses in household, individual and societal welfare. In 2010 dollars, the social welfare efficiency loss per ton abated ranges from $\$ 0.19$ to $\$ 3.90$ depending on the path of carbon prices. The only drawback to capital tax recycling is its regressivity. We find it to be regressive in full wealth at all but the highest rates of carbon taxation.

Reducing labor taxes promotes consumption and work through real-wage incentives and is the next most favorable recycling scheme. It favors the consumer sectors but with greater damage to the overall economy, larger revenue "haircuts", and bigger welfare losses. Here, the welfare loss per ton abated ranges from $\$ 11.09$ to $\$ 16.49$ depending on the carbon tax trajectory. The benefit from labor tax recycling is that it is 
unambiguously progressive for households, individuals, and society at all levels of carbon pricing.

The lump sum redistribution of carbon tax revenues is the least favorable recycling option. It incentivizes neither capital nor labor. Consequently, the damages to the economy and welfare are the greatest among the three schemes and the returned percentages of carbon tax receipts are the smallest. Under the lump sum treatment, the welfare loss per ton abated ranges from $\$ 37.15$ to $\$ 43.61$ as carbon taxation becomes more aggressive. While the welfare losses are the largest, this option, like labor tax recycling, is an instrument for greater equality. Though regressive in the relative sense, lump sum redistributions are progressive in the absolute sense and provide the best means for holding the poorest harmless from the welfare consequences of carbon taxation.

For capital and labor tax recycling, the losses in social welfare can be countered through a tax design that focuses on fossil fuel supplies and covers all uses at an economy-wide average burden. Strictly speaking, this is not a true double dividend since the social welfare gains are accompanied by smaller emissions reductions for a given carbon tax.

In the absence of a double dividend for society and the environment, the goal would be to construct a carbon tax recycling scheme that strikes an acceptable balance between losses for the former and gains for the latter while protecting the poor and improving overall equality. This should be achievable since we find welfare losses of only around $1 \%$ of lifetime wealth even under the highest of these carbon price scenarios.

\section{Acknowledgments}

This research report is prepared for the U.S. Environmental Protection Agency, Office of Atmospheric Programs. We are grateful for the comments, suggestions and contributions of our three referees.

\section{References}

Blonz, J, D Burtraw and MA Walls (2010). Climate policy's uncertain outcomes for households: The role of complex allocation schemes in cap-and-trade. The BE Journal of Economic Analysis and Policy, 10(2), Article 5, i-ii, 1-33.

Cohen, MA, D Fullerton and RH Topel (2013). Distributional Aspects of Energy and Climate Policies. Northampton, MA: Edward Elgar Publishing.

Dinan, T (2012). Offsetting a carbon tax's costs on low income households. CBO Working Paper 2012-16, Congressional Budget Office, Washington, DC. https://www.cbo.gov/publication $/ 43713$

Fullerton, D and G Heutel (2010). Analytical general equilibrium effects of energy policy on output and factor prices. The BE Journal of Economic Analysis and Policy, 10(2), Article 15, i-ii, 1-24 
Jorgenson, DW, RJ Goettle, MS Ho and PJ Wilcoxen (2013). Double Dividend: Environmental Taxes and Fiscal Reform in the United States. Cambridge, MA: The MIT Press.

Jorgenson, DW, RJ Goettle, MS Ho and PJ Wilcoxen (2017). IGEM: A Model of US Growth and the Environment. Version 20. Appendix A, Jorgenson et al. (2013). Double Dividend. Dale Jorgenson Associates, Cambridge, MA. Available at http://www.igem.insightworks. com/docs/.

Mathur, A and AC Morris (2012). Distributional effects of a carbon tax in the context of broader fiscal reform. Climate and Energy Economics Discussion Paper. Brookings Institution Climate and Energy Economics Project, Washington, DC.

Marron, D and E Toder (2013). Carbon taxes and corporate tax reform. Tax Policy Center, Urban Institute and Brookings Institution, Washington, DC.

Metcalf, GE, S Paltsev, JM Reilly, HD Jacob and J Holak (2008). Analysis of U.S. greenhouse gas tax proposals. MIT Joint Program on the Science and Policy of Global Change, Report No. 160, Cambridge, MA.

Parry, IWH and RC Williams III (2010). What are the costs of meeting distributional objectives for climate policy. The BE Journal of Economic Analysis and Policy, 10(2), Article 9, i-ii, $1-33$.

Rausch, S, GE Metcalf, JM Reilly and S Paltsev (2010). Distributional implications of alternative U.S. greenhouse gas control measures. The BE Journal of Economic Analysis and Policy, 10(2), Article 1, i-ii, 1-44.

Rausch, S and J Reilly, (2012). Carbon tax revenue and the budget deficit: A win-win-win solution? MIT Joint Program on the Science and Policy of Global Change, Report No. 228, Cambridge, MA.

U.S. Energy Information Administration (EIA) (2016). Monthly Energy Review (https://www. eia.gov/environment/data.php) and Annual Energy Outlook 2016 (https://www.eia.gov/ outlooks/aeo/er/tables_ref.php). The Department of Energy, Washington, DC.

U.S. Environmental Protection Agency (EPA) (2016). Inventory of U.S. Greenhouse Gas Emissions and Sinks: 1990-2014 (https://www.epa.gov/ghgemissions/inventory-us-greenhouse-gasemissions-and-sinks-1990-2014). EPA, Washington, DC.

Williams, RC III, H Gordon, D Burtraw, JC Carbone and RD Morgenstern (2014). The initial incidence of a carbon tax across income groups. Discussion Paper DP14-24. Resources for the Future, Washington, DC. 